UOPP \#438055, VOL 41, ISS 6

\title{
Advances in the Synthesis of 5- and 6-Substituted Uracil Derivatives
}

\author{
Javier I. Bardagí and Roberto A. Rossi
}

\section{QUERY SHEET}

This page lists questions we have about your paper. The numbers displayed at left can be found in the text of the paper for reference. In addition, please review your paper as a whole for correctness.

There are no Editor Queries for this paper.

\section{TABLE OF CONTENTS LISTING}

The table of contents for the journal will list your paper exactly as it appears below:

Advances in the Synthesis of 5- and 6-Substituted Uracil Derivatives

Javier I. Bardagí and Roberto A. Rossi 


\title{
Advances in the Synthesis of 5- and 6-Substituted Uracil Derivatives
}

\author{
Javier I. Bardagí and Roberto A. Rossi \\ INFIQC, Departamento de Química Orgánica, Facultad de Ciencias Químicas, \\ Universidad Nacional de Córdoba, Ciudad Universitaria, 5000 Córdoba, \\ ARGENTINA
}

INTRODUCTION

I. Uracils with Carbon-based Substituent ............................................... 3

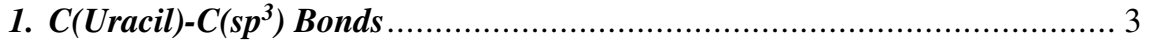

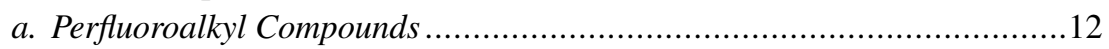

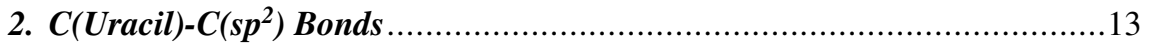

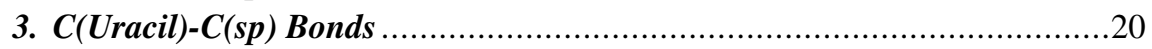

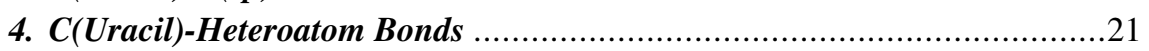

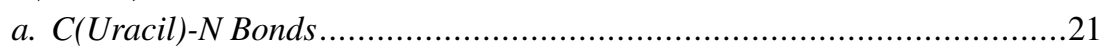

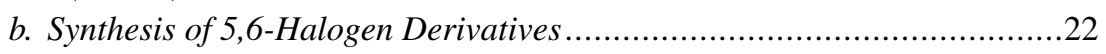

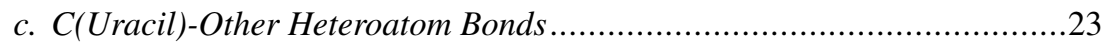

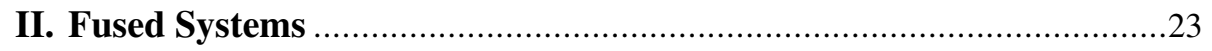

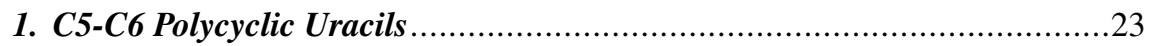

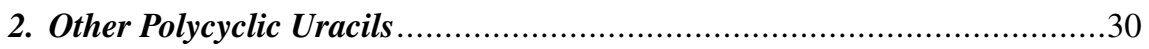

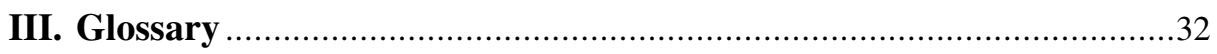

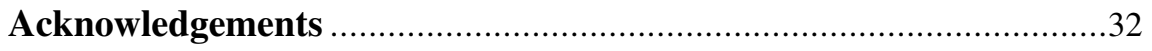

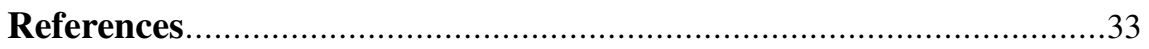




\section{7}

\title{
Advances in the Synthesis of 5- and 6-Substituted Uracil Derivatives
}

\author{
Javier I. Bardagí and Roberto A. Rossi \\ INFIQC, Departamento de Química Orgánica, Facultad de Ciencias Químicas, \\ Universidad Nacional de Córdoba, Ciudad Universitaria, 5000 Córdoba, \\ ARGENTINA
}

\section{INTRODUCTION}

The uracil unit is one of the most important structures in life, being part of the building blocks of RNA and DNA and other natural products. ${ }^{1}$ Therefore, it is not surprising that uracil derivatives have important biological activity. Uracil-based compounds are used in the treatment of cancer (5-fluorouracil) and against infections of the HIV virus (AZT). Actions as antiviral and antitumoral agents are perhaps the most widely reported activity. However, other uracil derivatives have been synthesized which are herbicides, insecticides, bactericides, acaricides, etc. In addition, uracil units can be found in the chemistry of peptide nucleic acid (PNA) or as part of other fused systems with antiallergic, antihypertensive, cardiotonic, bronchodilator or antibronchitis activity. ${ }^{2}$

The search for uracil derivatives has been carried out since the beginning of the last century and even today there is great interest in the development of new derivatives and strategies for synthesis so as to improve the yield of known compounds. To prepare uracils, there are three main synthetic strategies: a) building the uracil nucleus from acyclic precursors with appropriate substituents; b) modification of the structure of functionalized uracils or uracil itself by reaction with different reagents, as illustrated by the recent synthesis of 5-trifluoromethyluracil ${ }^{3}$ and uridines with oxiranyl and tetrahydrofuranyl substituents; ${ }^{4}$ c) functionalization of masked uracil moieties with reactions incompatible with the nucleus, for example the synthesis of 6-aryl and 6-acyluracils ${ }^{5}$ and $2^{\prime}$-deoxypseudouridine. ${ }^{6}$ Combinations of these approaches are often found in the synthesis of target compounds with potential biological activities.

The present review will cover advances in the synthesis of 5- and 6-substituted uracils (Figure 1) over the last 8-10 years. It has been organized in terms of the type of union that links the uracil moieties to the substitution groups; fused systems will have a separate section.

Received June 23, 2009; in final form September 4, 2009.

Address correspondence to Robert A. Rossi, INFIQC, Departamento de Química Orgánica, Facultad de Ciencias Químicas, Universidad Nacional de Córdoba, Ciudad Universitaria, 5000 Córdoba, ARGENTINA. E-mail: rossi@fcq.unc.edu.ar 
<smiles>O=c1cc[nH]c(=O)[nH]1</smiles>

Figure 1

\section{I. Uracils with Carbon-based Substituent}

\section{1. $C\left(\right.$ Uracil) $-C\left(s p^{3}\right)$ Bonds}

Chen et al. have synthesized 6-methyl (3) and 6-ethyluracils (7) using two different approaches as part of a study of polysubstituted uracils (Schemes 1 and 2). Uracil 3 was synthesized from a urea derivative $\mathbf{1}$ by reaction with diketene, to afford compound $\mathbf{2}$, which after reflux in acetic acid afforded uracil 3 (57\% from 1). ${ }^{7}$ Later the authors developed a more efficient strategy by using diketene, trimethylsilyl chloride, and NaI in $\mathrm{CH}_{3} \mathrm{CN},{ }^{8}$ obtaining 3 from $\mathbf{1}$ in one step in $95 \%$ yield.

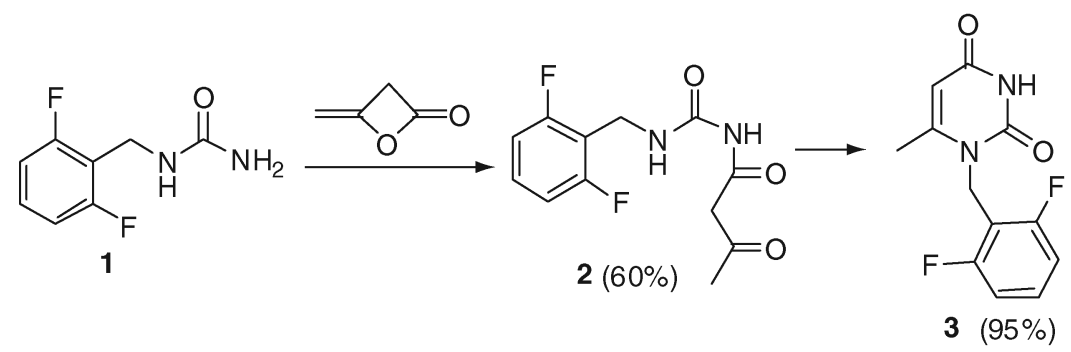

Scheme 1<smiles>CCOC(=O)CC(=O)OCC</smiles><smiles>[Y]n1c(CC)cc(=O)n([Tl])c1=O</smiles>

Scheme 2 
<smiles>N[C@@H](Cn1ccc(=O)[nH]c1=O)C(=O)O</smiles>

Figure 2

40

51 52

6-Ethyluracil 7 was prepared from 1,3-dialkyl-6-chlorouracil 4 (Scheme 2) ${ }^{9}$ by reaction with the anion of diethylmalonate to give 5; the treatment of $\mathbf{5}$ with $\mathrm{NaH}$ and MeI afforded 6, which by hydrolysis and double decarboxylation induced by $\mathrm{KOH}$ gave 7 in $19 \%$ overall yield.

In a study of glutamate agonists and antagonists, Young and co-workers used their "ring switching" strategy to prepare a willardiine (Figure 2) isomer 2-(pyrimidin-2,4-dione-5-ylmethyl)-(2S)-glycine (9) from heterocycle $\mathbf{8}$ (Scheme 3$).{ }^{10}$

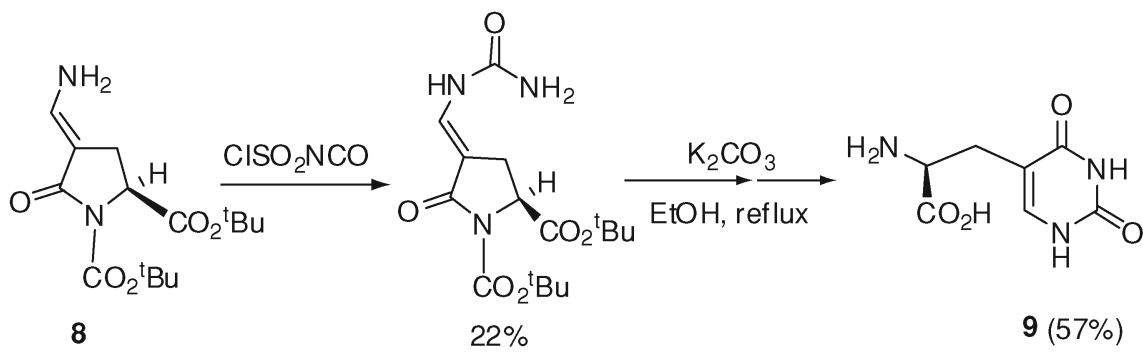

Scheme 3

A synthesis of 5-benzyluracils (13) from Baylis-Hillman adducts (10) was developed by Kim et al. (Scheme 4). ${ }^{11}$ Substitution of acetate by primary amines gave $\mathbf{1 1}$ in moderated

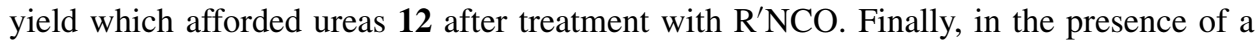
base, $\mathbf{1 2}$ cyclized to afford uracil $\mathbf{1 3}$ in good yields.

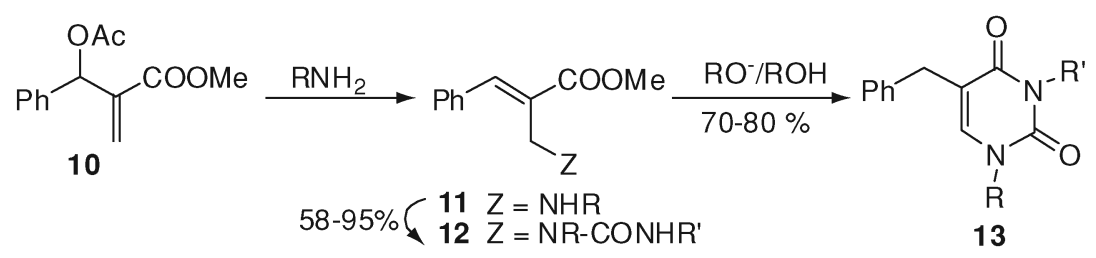

\section{Scheme 4}

Batra et al. synthesized 1,5-disubstituted uracils 17 using the same approach with a slight modification using BrCN instead of R'NCO (Scheme 5). ${ }^{12}$

Recently, Cao and Huang developed a solid-phase synthetic strategy for the synthesis of uracil and 6-methyluracils bonded to different heterocycles through N1 or N3, starting from 


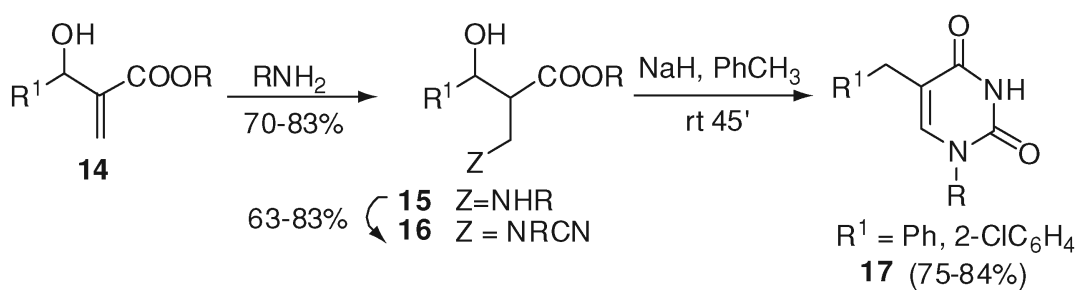

Scheme 5

$\alpha, \beta$-unsaturated esters and amines. ${ }^{13} \mathrm{~A}$ selenopolystyrene resin was used and good yields (41-75\%) and moderate to good purity (64-96\%) were obtained (Scheme 6). However, the inclusion of larger group at 6-position, like aryl or isopropyl, was not possible. As a result, this strategy seems to be an excellent option for variation of N1 and N3 subtitutient but it has a very limited utility in the synthesis of C5 or C6 derivatives.

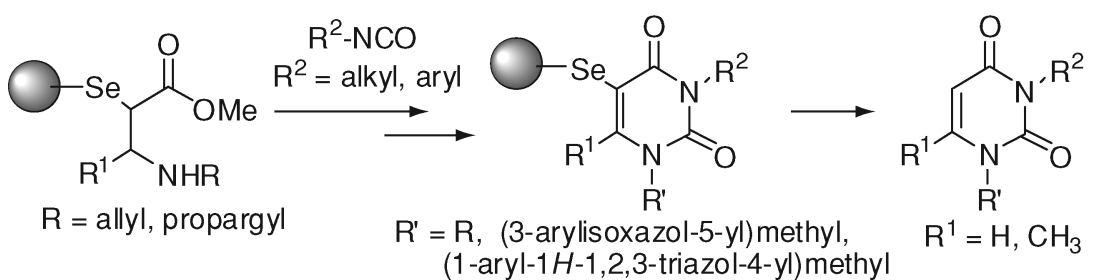

Scheme 6

Yano et al. have synthesized a family of 6-methylene-bridged uracil derivatives, ${ }^{14,15}$ in the search for an inhibitor of thymidine phosphorylase (TP) better than 6-amino-5chlorouracil, a known TP inhibitor. The authors were indeed able to obtain a more potent inhibitor of TP and with better properties (solubility and oral absorption). The synthesis of the aminomethyluracils (19) was accomplished through the reaction 5-halo-6chloromethyluracils (18) with the appropriate amines (Scheme 7). Most of the reactions were carried with the amine in water as solvent and the yield obtained ranged from very low ( $1 \%$ ) to excellent (93\%); however, some reactions were not optimized in order to obtain the best yields possible. More than twenty-five amines were used, including acyclic and cyclic ones, diamines and aminoalcohols, among others.

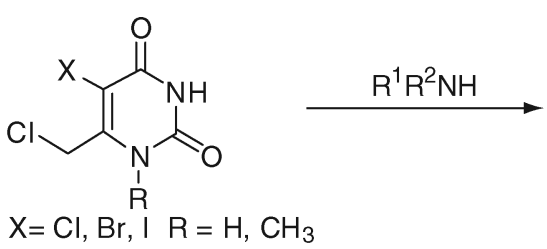

18<smiles>[R7]NCc1c([Y])c(=O)[nH]c(=O)n1P</smiles>

19

Scheme 7

70

71

72

Later on Corelli et al. published their microwave (MW) assisted synthesis of the same type of compounds in methanol as solvent, ${ }^{16}$ starting from $\mathbf{1 8}(\mathrm{R}=\mathrm{H}, \mathrm{X}=\mathrm{Cl})$ 
by reaction with different amines. Uracil 19a $\left(\mathrm{R}^{1}=\mathrm{H} ; \mathrm{R}^{2}=\left(\mathrm{CH}_{2}\right)_{2} \mathrm{NH}_{2}\right)$ was prepared from the protected 19b $\left(\mathrm{R}^{1}=\mathrm{H} ; \mathrm{R}^{2}=\left(\mathrm{CH}_{2}\right)_{2} \mathrm{NH}-\mathrm{Boc}\right)$. Derivative 19c $\left(\mathrm{R}^{1}=\mathrm{H} ; \mathrm{R}^{2}=\right.$ $\left.\left(\mathrm{CH}_{2}\right) \mathrm{NHC}(\mathrm{NH}) \mathrm{NH}_{2}\right)$ was also prepared from 19a by reaction with $S$-methylisothiourea.

A series of guanidine, amidino and thioureido derivatives were synthesized from 6-aminomethyl-5-chlorouracil under different conditions (Scheme 8). ${ }^{15}$

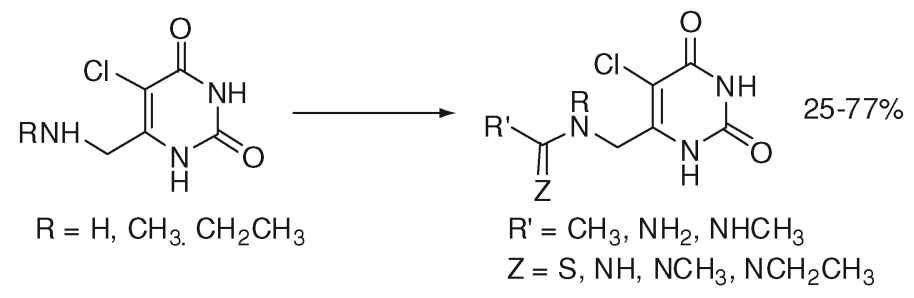

Scheme 8

5-Dihydropyrimidine-uracils (21) were synthesized by Knaus and co-workers ${ }^{17}$ from 5-formyluracil (20) using a three-component Hantzsch reaction (Scheme 9).

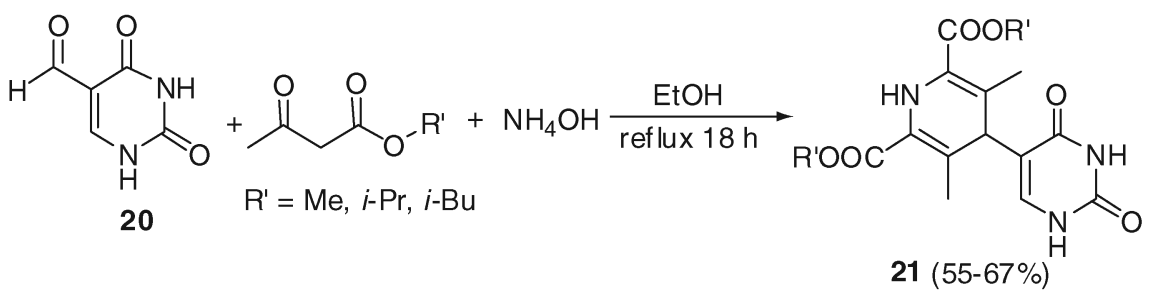

\section{Scheme 9}

Looking for a convenient synthesis of monofluorinated-alkyl uracils, Kung and coworkers have developed a direct alkylation of nucleosides at the 5-position. ${ }^{18} \mathrm{~A} \mathrm{Pd}$-catalyzed Negishi cross-coupling reaction of $\mathbf{2 2}$ and unactivated monosubstituted alkylzinc bromides (23) was used to prepared 5-alkyluracils 24 with moderate yield carrying -F (43-53\%), esters, - CN, - $\mathrm{OSiR}_{3}(29-39 \%)$ functional groups (FG) (Scheme 10). However, the method has the limitation of providing low yields of products $(0-8 \%)$ when the alkyl chain is short (propyl, ethyl).

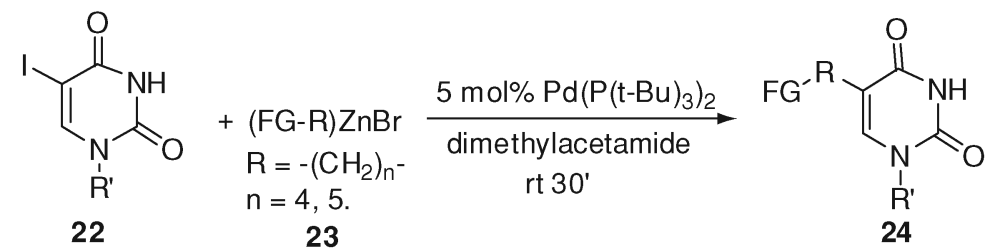

\section{Scheme 10}

Kumar et al. employed an indium catalyst to prepare the 5-substituted uracils (26 and 28) from 5-formyluracils (25) and from the Schiff bases of $\mathbf{2 5}$ (Scheme 11 and 12). ${ }^{19}$ Allylation of $\mathbf{2 5}$ with bromoallyl compounds in the presence of indium metal in a mixture of THF: $\mathrm{H}_{2} \mathrm{O}$ (1:1) gave compound $\mathbf{2 6}$ in moderate to good yields (Scheme 11); diastereomeric 


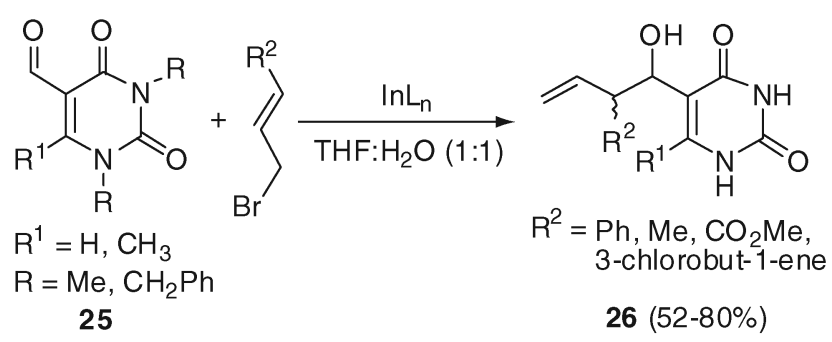

Scheme 11

ratios of $>99: 1$ were obtained in the best case. They suggest that the high diastereoselectivity of the reaction results from the complexation of the C-4 carbonyl oxygen of the uracil.

From the Schiff bases 27a, amines 28a were obtained in $68-70 \%$ yield. The authors were able to obtain a moderate yield and good diastereocontrol of the uracil $\mathbf{2 8 \mathbf { b }}$ derived from chiral $\mathrm{R}^{2}$ (27b) (Scheme 12).<smiles>[R]N=Cc1c([R7])n([R])c(=O)n([R])c1=O</smiles>

27a: $\mathrm{R}^{2}=4-\mathrm{O}_{2} \mathrm{NC}_{6} \mathrm{H}_{4}, 4-\mathrm{H}_{3} \mathrm{CC}_{6} \mathrm{H}_{4}$

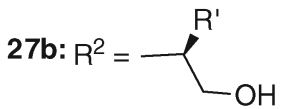
$\mathrm{R}^{\prime}=\mathrm{Ph}, \mathrm{CH}_{2} \mathrm{Ph}, i-\mathrm{Pr}$<smiles>[R]NC(CC=C)c1c([R7])n([R])c(=O)n([R])c1=O</smiles>

28a $(68-70 \%)$

$28 b(62-68 \%, d r>98: 2)$

Scheme 12

More recently, Vasella et al. have used 6-(diazomethyl-1,3-bis(methoxymethyl)uracil 29 (see Scheme 34) to prepare 6-substituted uracil 30 (Scheme 13) by reactions with thiophene through a Rh(II) catalyst. $^{20}$<smiles>COCn1c(C=N)cc(=O)n(COC)c1=O</smiles>

Scheme 13

98

101

102

103

The synthesis of tetrasubstituted uracils from one alkyne and two isocyanates using a $\mathrm{Ni}(0)$ catalyst was reported by Duong and Louie. ${ }^{21}$ They optimized the conditions to prepare 5-TMS-6-alkyl (methyl, $t$-butyl and $i$-propyl) uracils 31 in good yields (Scheme 14). The proposed mechanism involves an oxidative coupling between a molecule of alkyne and isocyanate which gives the nickel intermediate 32 (Scheme 15). Reaction with another 


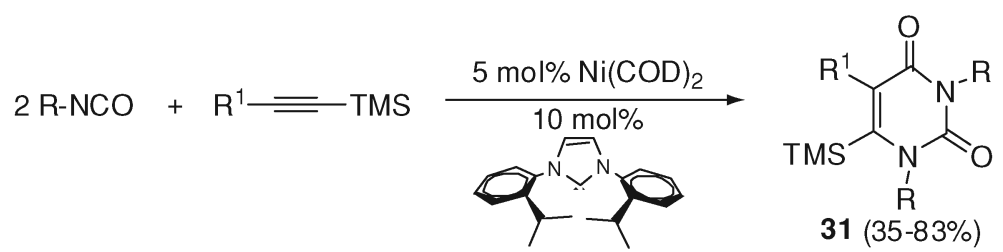

Scheme 14

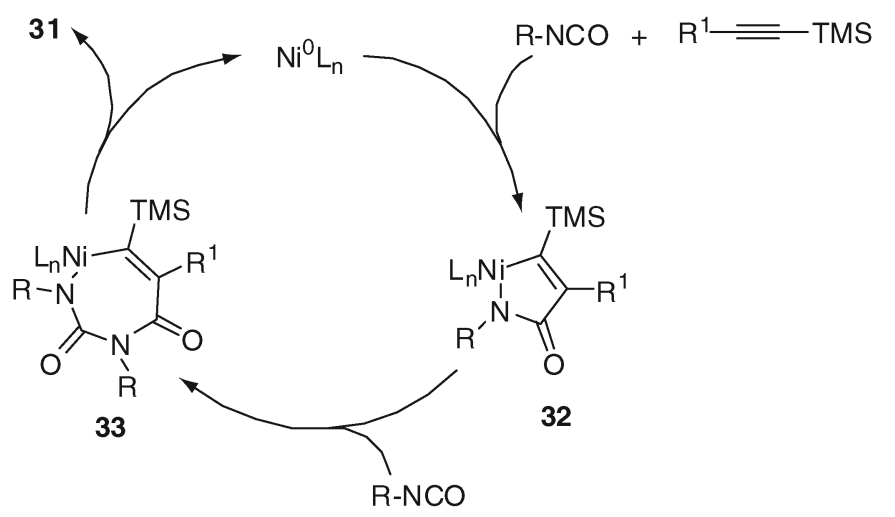

Scheme 15

molecule of isocyanate is suggested to give compound $\mathbf{3 3}$ which, after reductive elimination, gives uracil products $\mathbf{3 1}$ and the $\mathrm{Ni}(0)$ catalyst which continues the catalytic cycle.

In search for new uracil derivatives, Saladino et al. synthesized a series of uracil and uridines with oxiranyl and tetrahydrofuranyl substituents (Scheme 16-19) and evaluated their biological activity toward the Sendai virus, finding potent and selective antiviral activity. ${ }^{4}$ The authors used a metalation-alkylation sequence developed previosly ${ }^{22}$ from 34 , which gave the anion $34^{-}$when treated with lithium diisopropylamide (LDA), and then the anion trapped with $\alpha$-chloroketones 35 giving the oxiranyl methyl uracils 36 (Scheme 16).

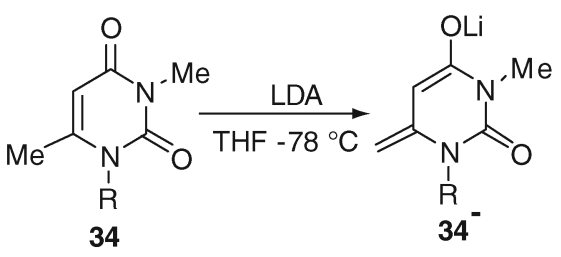

34

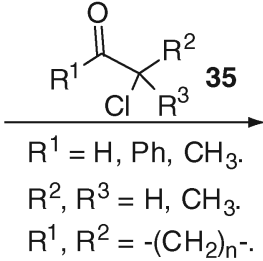

$R^{1}, R^{2}=-\left(\mathrm{CH}_{2}\right)^{-}$.

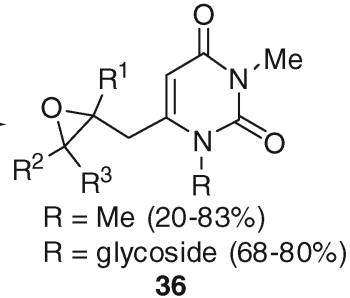

36
111

Scheme 16

The reaction of lithium enolate $34^{-}(\mathrm{R}=\mathrm{Me})$ with $\gamma$-chloroketones gave tetrahydrofuranylmethyl uracils (37); however, the yields were low (Scheme 17). The reaction of $\mathbf{3 4}^{-}$ $(\mathrm{R}=$ glycoside) with 3-chloropropyl-methyl ketone afforded 38 in modest yield.

With a similar approach, uracil precursor 39 afforded oxiranylmethyl derivative $\mathbf{4 0}$ and tetrahydrofuranylmethyl analogues 41 (Scheme 18). 


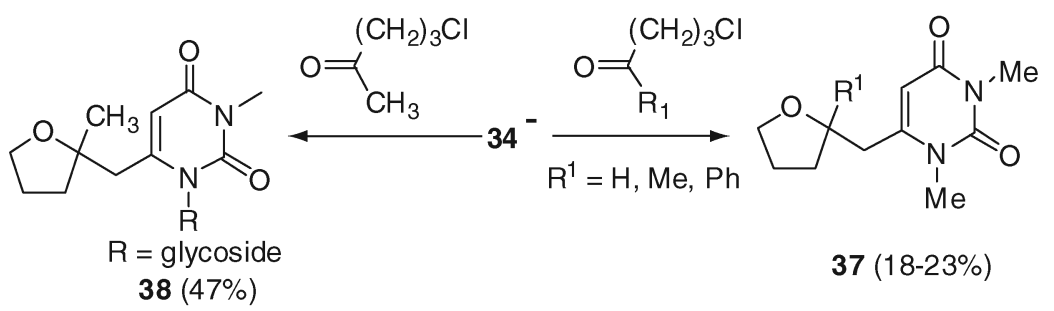

Scheme 17

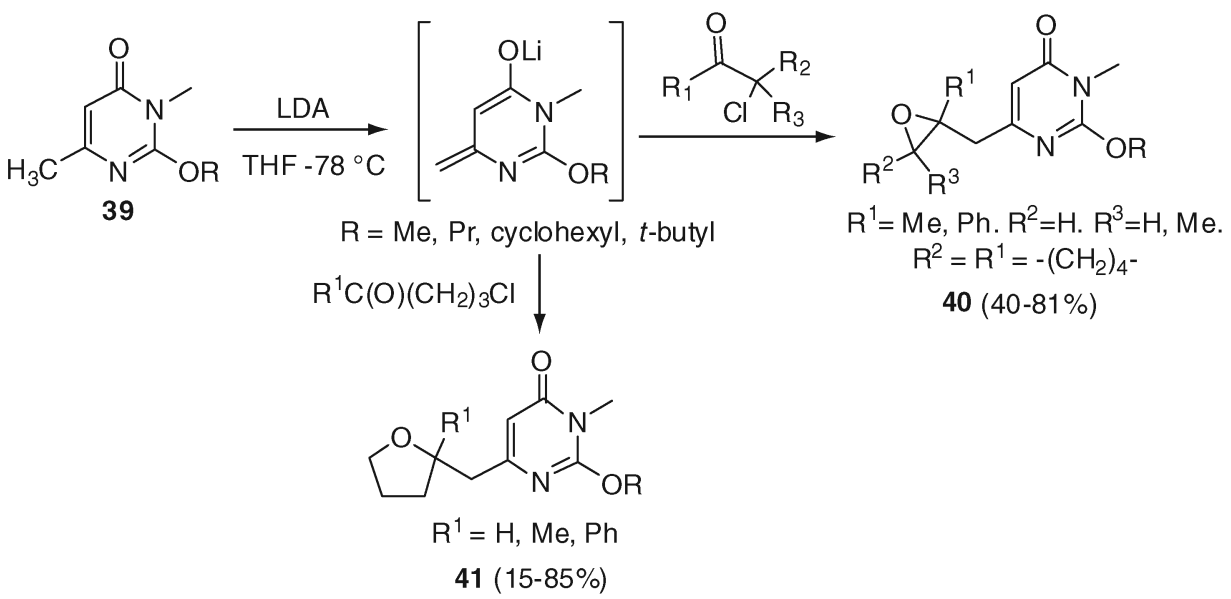

Scheme 18

The use of 6-chloromethyl-1,3-dimethyluracil (42) instead of $\mathbf{3 9}$ allowed the preparation of 6-oxiranyl uracils $\mathbf{4 3}$ in acceptable yields after reaction with ketones (Scheme 19).

Lithiation of 5-iodo- $2^{\prime}$-deoxyuridine sodium salt was accomplished by Suemune et al. to give compound 44, used to prepare different 5-substituted-2'-deoxyuridines (45) in good yield by reaction with $\mathrm{MNP}, \mathrm{CH}_{3} \mathrm{I}, \mathrm{CD}_{3} \mathrm{OD}, \mathrm{TMSCl}, \mathrm{PhCHO}$ and $\mathrm{CH}_{3} \mathrm{SSCH}_{3}$ as electrophiles (E+, Scheme 20). ${ }^{23}$

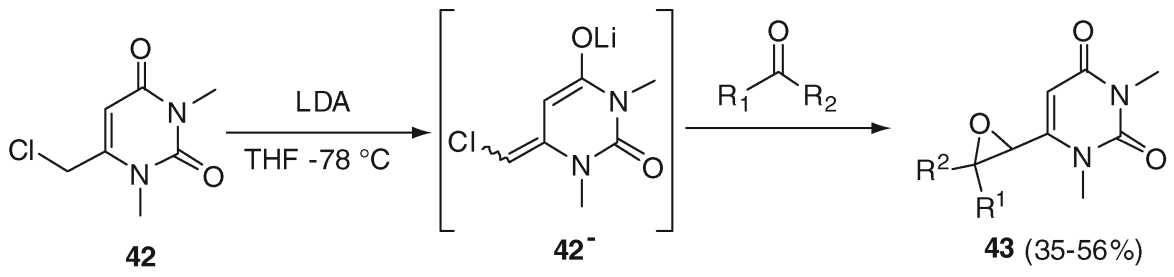

Scheme 19

Reese and $\mathrm{Wu}^{6}$ synthesized 5-(2-deoxy- $\beta$-D-ribofuranosyl)-2,4-dioxo-pyrimidine (2'deoxypseudouridine, 49) as part of a study oriented to the synthesis of monomers for the antigen approach to oligonucleotide-based chemotherapy. In contrast to other synthesis of 49, 2-deoxy-D-ribose was used as the source of the sugar to prepare lactone 47 (Scheme 21). 


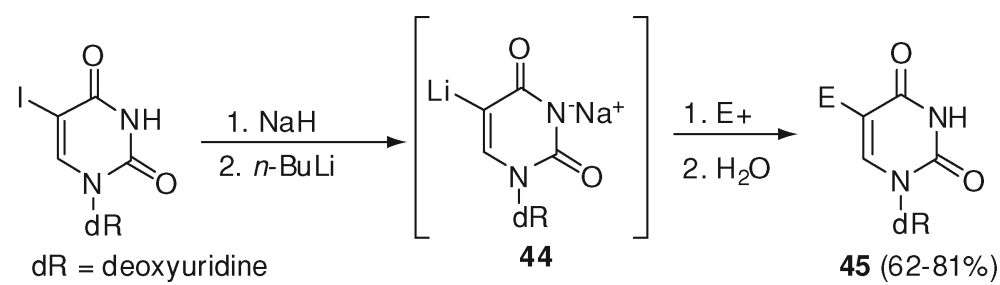

Scheme 20

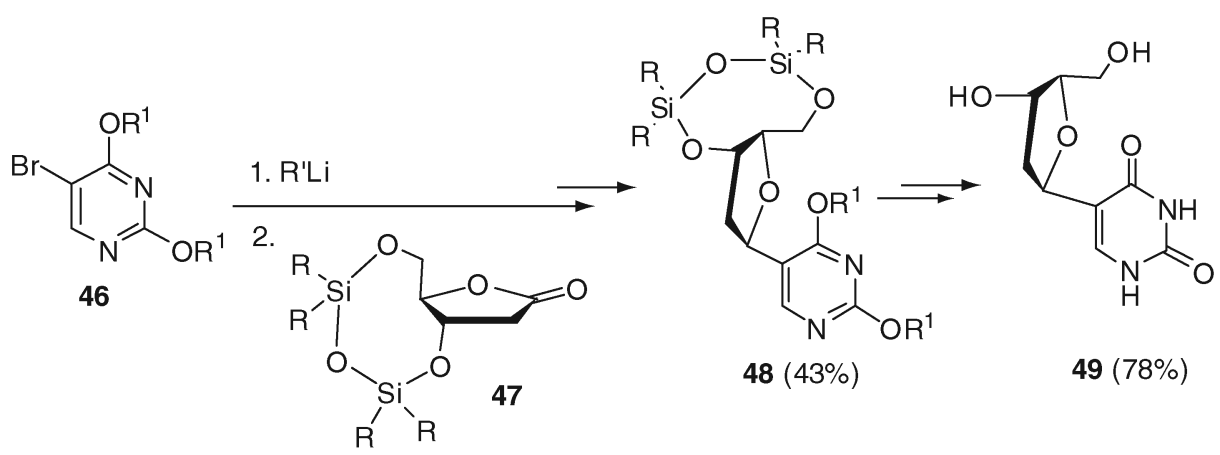

Scheme 21

Compound 46 was lithiated and allowed to react with 47 giving an acyclic compound, which after reduction and cyclization (under Mitsunobu conditions) afforded the protected product 48. The latter compound was deprotected to yield 49.

(-)-7-Epiculindospermopsin (57) is an example of a complex 6-substituted uracil derivative; the total synthesis of this compound was developed by White and Hanses. ${ }^{24}$ They used a masked uracil nucleus, 2,4-dimethoxypyrimidine, which gave the uracil in the penultimate step of the synthesis. The synthesis of $\mathbf{5 7}$ was developed from barbituric acid in 23 steps $(0.6 \%)$. The authors proposed the synthesis of $\mathbf{5 7}$ from two fragments 53 and 54 (Scheme 22). Synthesis of 53 started with the preparation of 4-bromo-2,6dimethoxypyrimidine $\mathbf{5 0}$ from barbituric acid (83\%). $\mathbf{5 0}$ was then lithiated and allowed to react with 51 to give $\mathbf{5 2}$ in $97 \%$ yield, then $\mathbf{5 2}$ was transformed to $\mathbf{5 3}$ in 7 steps (34\% from 52). The reaction of $\mathbf{5 3}$ and $\mathbf{5 4}$ afforded $\mathbf{5 5}$ in $60 \%$ yield. The nitrile oxide was transformed to 56 in 13 steps in $3.8 \%$ yield, the last step being the deprotection of the uracil with $\mathrm{HCl}$. Finally, sulfation of $\mathbf{5 6}$ gave 57 (63\%).

Boudet and Knochel used an improved bromine/magnesium exchange of 5-bromo-6halo-2,4-dimethoxypyrimidine (58) to prepare 5,6-disubstituted uracils. ${ }^{25}$ The use of one equivalent of the magnesium reagent gave a regioselective substitution of the halogen in position 5, affording 6-halo-5-substituted-2,4-dimethoxypyrimidines (59) with good yields $(70-91 \%)$ by reaction with different electrophiles $\left(\mathrm{E}^{1}+\right)$, such as aldehydes, acyl chlorides, allyl and benzyl bromide, TMSCl, and TsCN (Scheme 23). Access to 5,6-substituted uracils 60 was possible in two successive steps (69-81\%) without the need to isolate 59.

Oxypurinol 61 and emyvirine 62 (Scheme 24) were prepared as an application of this methodology, where hydrolysis with $\mathrm{HCl}$ in $\mathrm{MeOH}$ at reflux was used to convert the 2,4-dimethoxypyrimidines into uracils. 
<smiles>COc1cc(Br)nc(OC)n1</smiles>

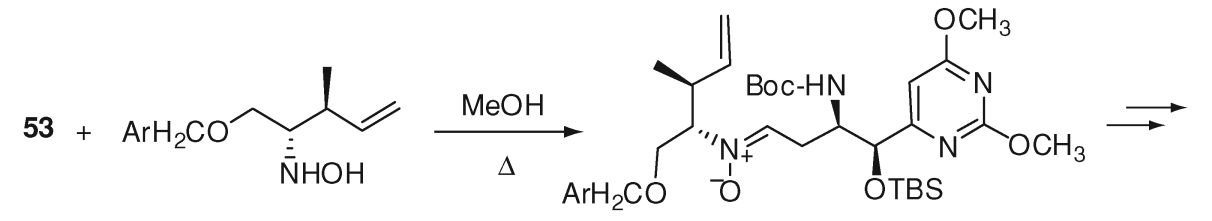

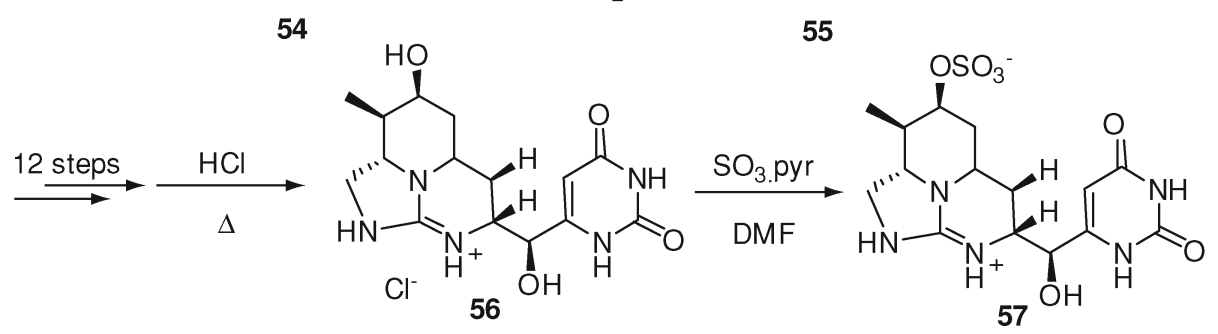

Scheme 22<smiles>[Z]c1nc(OC)nc(OC)c1Br</smiles>

$58, \mathrm{X}=\mathrm{Cl}, \mathrm{Br}$ 59

60

Scheme 23

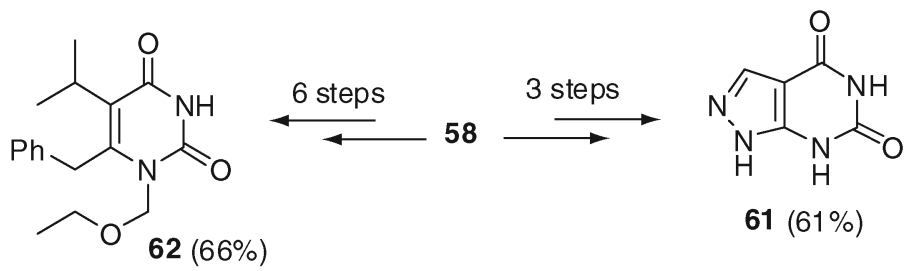

Scheme 24

In the same type of studies with magnesium compounds, Kopp and Knochel synthesized uracils without the need to protect the acidic proton of uracil (Scheme 25). ${ }^{26}$ They prepared the tri-anion 64 from 5- and 6-iodouracils 63 and allowed it to react with different electrophiles (aldehydes, bromides, alkenes) obtaining good yields of the substitution products $\mathbf{6 5}$ (Scheme 25). The authors were able to synthetize a precursor (65) of emivirine $62\left(\mathrm{X}=i-\mathrm{Pr}, \mathrm{Y}=\mathrm{CH}_{2} \mathrm{Ph}\right)$. 
<smiles>[X]c1[nH]c(=O)[nH]c(=O)c1[X]</smiles>

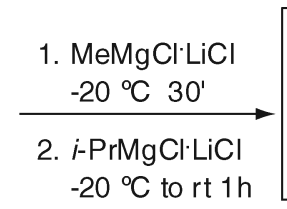

63a $(X=I, B r . Y=H)$ 63b $(X=H$, alkyl. $Y=I)$<smiles>[Y]c1nc(OC)nc(OC)c1[X]</smiles>

64a $(X=\mathrm{MgCl} . Y=\mathrm{H})$

64b $(X=H$, alkyl. $Y=M g C l)$<smiles>[Y]c1[nH]c(=O)[nH]c(=O)c1[X]</smiles>

54-84\%

65a $(X=E . Y=H)$

65b $(X=H$, alkyl. $Y=E)$

\section{Scheme 25}

\section{a. Perfluoroalkyl Compounds}

Perfluoroalkyl derivatives are an important class of the family of uracil compounds because of the special properties provided by fluoro atom. Compared to the synthesis of alkyl derivatives, perfluoro derivatives have been less explored, probably due to the difficulties found in the chemistry of perfluoroalkylated compounds.

Savéant et al. have used an electrochemically-induced $\mathrm{S}_{\mathrm{RN}} 1$ reaction to prepare 5perfluoroalkyluracils in moderate yield (Scheme 26). ${ }^{27}$

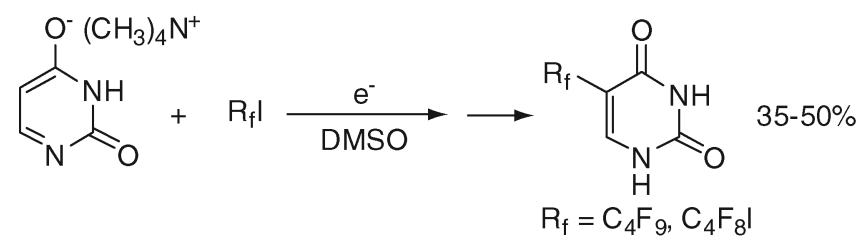

\section{Scheme 26}

Strekowski et al. ${ }^{28}$ synthesized 5-perfluoroalkyluracils 67 from 5-bromo-2,4diethoxypyrimidine (66) and iodoperfluoroalkanes in two steps (Scheme 27). They used a known procedure which utilized a $\mathrm{Cu}$-Bronze reagent to prepare uracils 67 with better yield than those previously reported. ${ }^{29}$

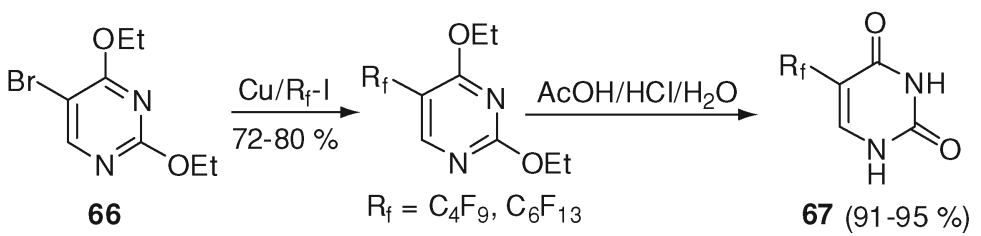

\section{Scheme 27}

6-Perfluoroalkyl uracils and thiouracils (3-aryl and 3-alkyl) have been prepared from esters, perfluorinated nitriles, and iso(thio)cyanates (Scheme 28). ${ }^{30}$ The first step of the synthesis involves the reaction of the enolate of ester $\mathbf{6 8}$ with the nitriles to give fluorinated $\beta$-enamino esters (69), which after treatment with $\mathrm{NaH}$, reacts with iso- and isothiocyanates to afford uracils $\mathbf{7 0}$ in good yields. The methodology seems to be useful to prepare even 5,6-disubstituted uracils. 


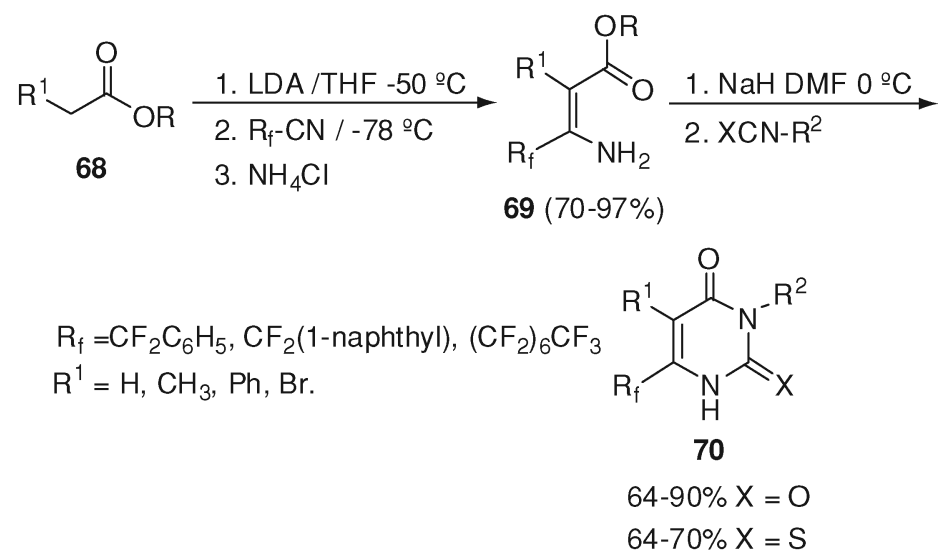

Scheme 28

The good results obtained encouraged the authors to perform the synthesis of the same compounds through a solid-phase approximation. Linking the ester to a Wang resin $(\mathrm{R}=$ resin in Scheme 28$)$ they were able to prepare 3-aryl and 3-alkyl-6(difluorophenylmethyl)uracils in good yields (67-89\%) with moderated to very good purity (65-99\%); thiouracils were also prepared, but the yields and purity were lower (55-63\% and $61-73 \%) .{ }^{30}$

The fluorous synthesis with tagged ester $\left(\mathrm{R}=\mathrm{R}_{\mathrm{f}}\right.$, Scheme 27$)$ was accomplished more recently. ${ }^{31}$ The uracils $70\left(\mathrm{R}^{1}=\mathrm{H}, \mathrm{R}_{\mathrm{f}}=\mathrm{CF}_{2} \mathrm{CH}_{2} \mathrm{CH}=\mathrm{CH}_{2}, \mathrm{R}^{2}=\right.$ aryl, alkyl $)$ were obtained with good yields (52-99\%).

Recently, 5-trifluoromethyl uracils were synthesized from uracil and $\mathrm{CF}_{3} \mathrm{I}$ in modest to excellent yields using a catalytic system of $\mathrm{FeSO}_{4}, \mathrm{H}_{2} \mathrm{O}_{2}$ and $\mathrm{H}_{2} \mathrm{SO}_{4} \cdot{ }^{3}$ The authors were able to scale the synthesis to the use of $40 \mathrm{Kg}$ of uracil. Using this approach to prepare 5-trifluoromethyl derivatives from substituted uracils was also successful (Scheme 29).

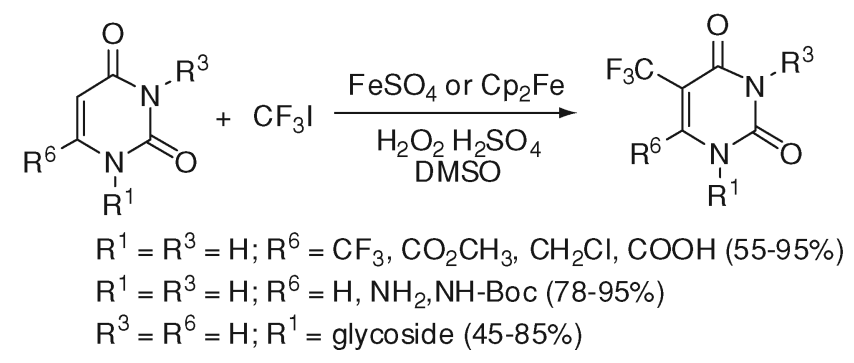

Scheme 29

187

\section{2. $C($ Uracil $)-C\left(s p^{2}\right)$ Bonds}

189 The synthesis of 5-methyl-1,6-diphenyluracil and 5-methyl-6-phenyl-1-(phenylmethyl)

190 uracil (72) was performed from the Baylis-Hilman adducts 10 described in Section I.1)

191 (Scheme 4) through cyclization of the urea 71 (Scheme 30). ${ }^{11}$ 


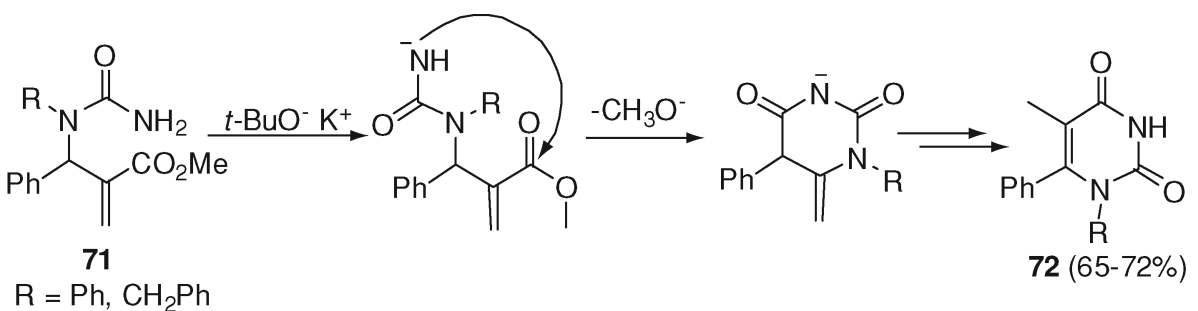

Scheme 30

Searching for a rapid and economical screening of inhibition of human deoxyuridine triphosphate nucleotidohydrolase (dUTPasa) and human nuclear uracil DNA glycosylase (UNG2), Stivers et al. developed a strategy to prepare tris-uracil oximes from oxyamine 73, 5-formyluracil (74) and aryl aldehydes (Scheme 31). ${ }^{32}$ The synthesis involved reaction in DMSO at $37^{\circ} \mathrm{C}$; a mixture of the homotrimeric (75 and 76) and heterotrimeric (77 and 78) compounds were obtained. More than two hundred aryl aldehydes were used and the mixtures were screened for active compounds without purification of the mixtures.

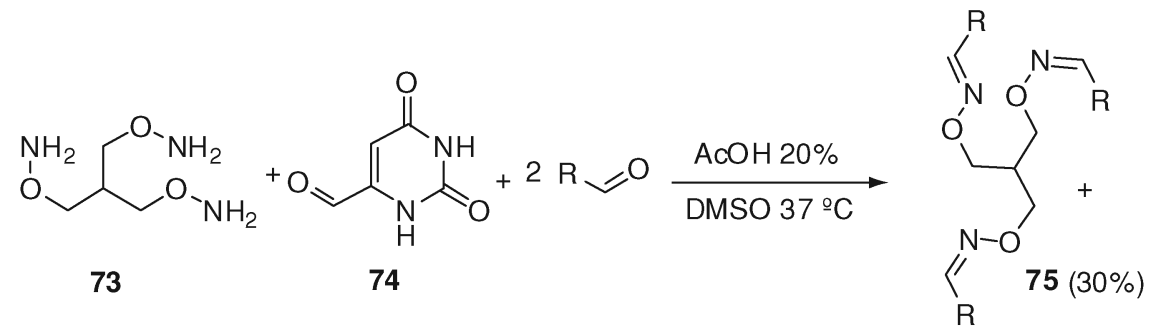<smiles>O=c1cc(/C=N/OCC(CO/N=C/c2cc(=O)[nH]c(=O)[nH]2)CO/N=C/c2cc(=O)[nH]c(=O)[nH]2)[nH]c(=O)[nH]1</smiles>
$76(4 \%)$<smiles>[R]C=NOCC(CO/N=C/c1cc(=O)[nH]c(=O)[nH]1)CO/N=C/c1cc(=O)[nH]c(=O)[nH]1</smiles>

$77(22 \%)$
$\mathrm{R}$<smiles>[R]C=NOCCCO/N=C\[R]</smiles>

\section{Scheme 31}

As part of a study on the reactions of metal $(\mathrm{Cr}, \mathrm{W})$ carbene complexes, Ricart et al. synthesized monoalkyl (1 or 3) and 1,3-dialkyl-6-phenyluracils via reaction of carbenes $\mathbf{7 9}$ with substituted ureas, followed by oxidation of the metal carbonyl complex $\mathbf{8 0}$ to $\mathbf{8 1}$ (Scheme 32). ${ }^{33-35}$

The synthesis of complexes $\mathbf{8 0}$ was accomplished at room temperature under MW irradiation with good yields that were better than with conventional heating, ${ }^{33,34}$ with shorter reactions times (days to hours) and allowing the reactions to be performed, in some cases, without solvent. The authors studied several oxidants ${ }^{35}$ to transform $\mathbf{8 0}$ into $\mathbf{8 1}$ and 


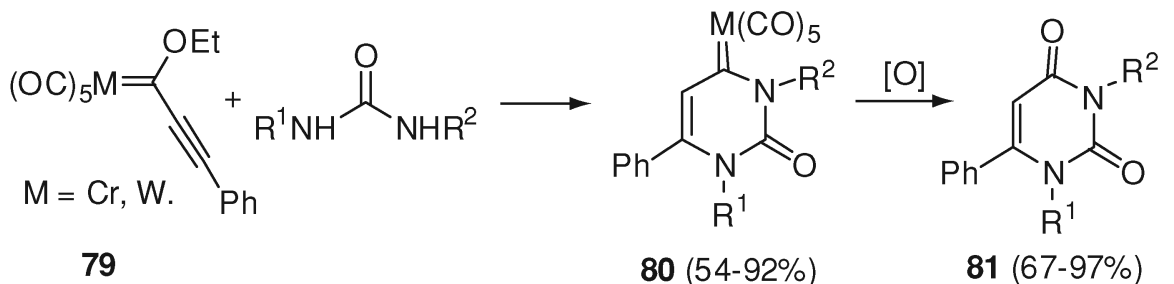

Scheme 32

found that the use of TABF open to $\operatorname{air}^{36}$ and $t$-butyl hydroperoxide were the most generally useful reagents.

Using $\mathrm{Ni}(0)$ as catalyst (see Scheme 14), Duong and Louie ${ }^{21}$ prepared 6-carbonyl and 6-vinyl-5-(trimethylsilyl)uracils (82) from one alkyne and two isocyanates (Scheme 33) in moderate yields (38-43\%). Although the synthesis of 5,6-diphenyl derivatives was not possible, the stannane $82\left(\mathrm{R}^{1}=\mathrm{SnBu}_{3}, \mathrm{R}^{2}=\right.$ methyl, $\mathrm{R}=$ ethyl $)$ was prepared using this approach and reaction with $\mathrm{PhI}$ in a Stille reaction $\left(\mathrm{Pd}\left(\mathrm{PPh}_{3}\right)_{4}, \mathrm{CuI}, \mathrm{DMF} 60^{\circ} \mathrm{C}\right)$, gave 6-methyl-5-phenyl-1,3-diethyluracil in 75\% yield in the two steps.

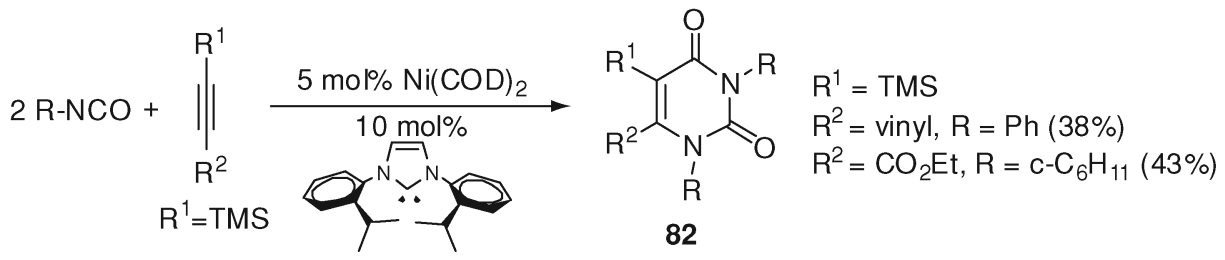

Scheme 33

Recently, Vasella et al. have prepared a versatile 6-diazomethyuracil derivative $\mathbf{2 9}$ (Scheme 34$){ }^{20}$ The synthesis started with 6-formyl-1,3-dimethoxymethyluracil (83) which, after reaction with $\mathrm{NH}_{2} \mathrm{NH}_{2}$, gave hydrazone 84 in $84 \%$ as a mixture of $E / Z$ isomers in a ratio of 9:1. This mixture was allowed to react with $\mathrm{MnO}_{2}$ to give compound 29 in $90 \%$ yield.

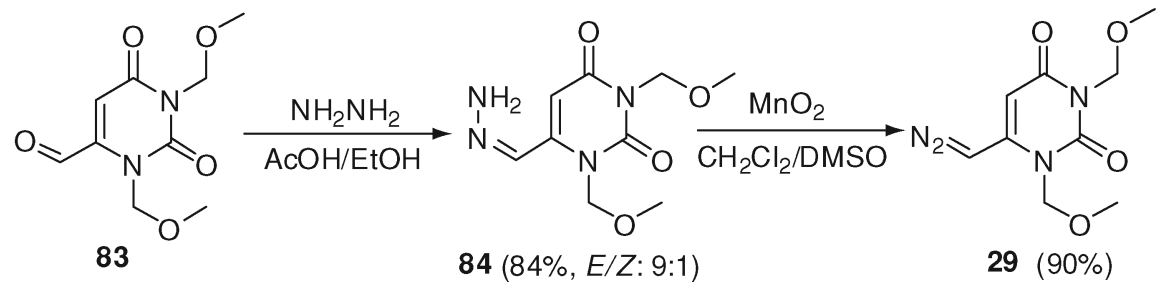

Scheme 34

Reactions of compound 29 in the presence of $\mathrm{Rh}(\mathrm{OAc})_{2}$ in $\mathrm{CH}_{2} \mathrm{Cl}_{2}$ afforded dimeric compounds 85 as a mixture of $Z(45 \%)$ and $E(22 \%)$ isomers (Scheme 35$)$ through the formation of carbenoids. Deprotection of 85 with $\mathrm{BBr}_{3}$ gave diuracil 86 in moderate yield (Z (52\%) and $E(58 \%))$. 


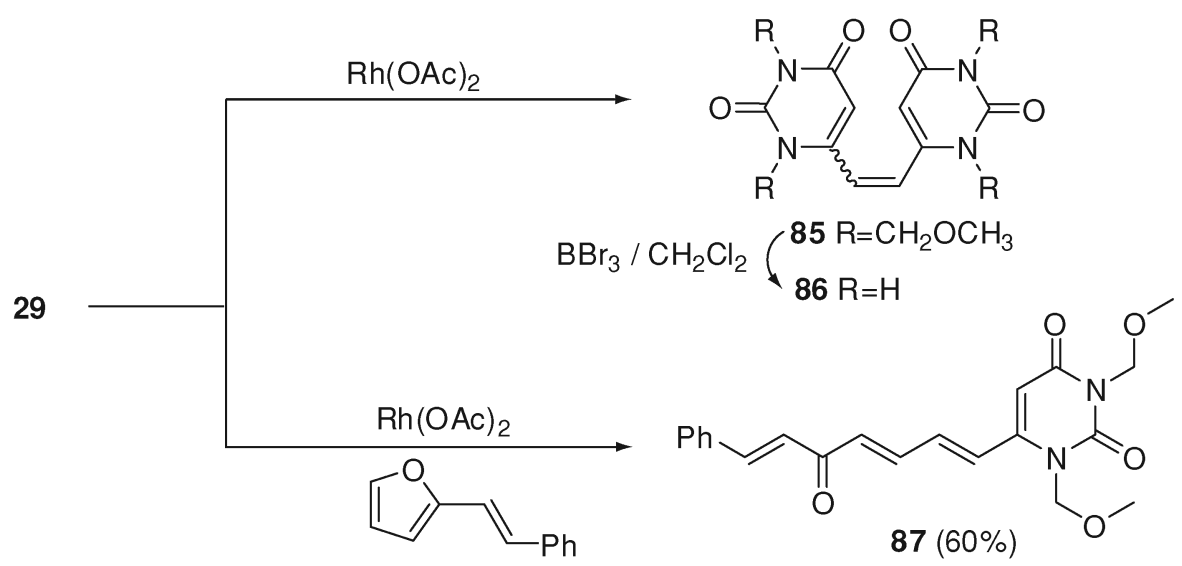

Scheme 35

Reactions induced by $\mathrm{Rh}(\mathrm{OAc})_{2}$ in the presence of different carbenophiles afforded 6substituted and fused compounds (see Scheme 13 and Scheme 70-72). When 2-styrylfuran was used as the carbenophile, ketone $\mathbf{8 7}$ was obtained as a mixture of four $E / Z$ isomers. However when the reaction was allowed to equilibrate during seven days, it afforded (E,E,E)-87 in 60\% (Scheme 35).

From 2003 to 2005, a series of polysubstituted uracils were synthesized by Chen et al. in a study of gonadotropin receptor antagonists. They used a Pd-catalyzed Suzuki-Miyaura reaction to synthesize 5-aryluracils (89) from 5-halouracils (88) (Scheme 36). Aldehyde, amino, methylaryl as well as chiral structures were used as substituents in positions 1 and 3 in substrate 88. Boronic acids or pinacol esters of 1-naphtyl, 2-dibenzofuranyl ${ }^{37}$ and phenyl with $\mathrm{OCH}_{3}, \mathrm{OH}, \mathrm{OCF}_{3}, \mathrm{OPh}$, alkyl, ${ }^{37,38,39} \mathrm{~F}, \mathrm{Cl}, \mathrm{SCH}_{3}, \mathrm{OR}$ and alkenyl groups as substituents ${ }^{37,39}$ were used to obtain moderate to good product yields.

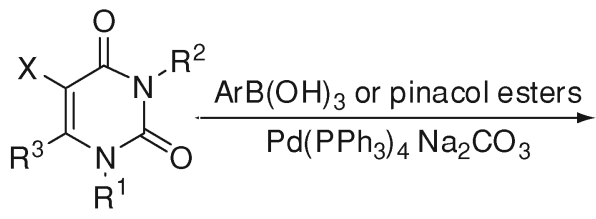
$\mathrm{X}=\mathrm{Br}, \mathrm{I}$.

88<smiles>[R]c1c([Hg])c(=O)n([R])c(=O)n1[R7]</smiles>

$\mathrm{R}_{3}=\mathrm{CH}_{3}, \mathrm{H}$. $89(30-91 \%)$

\section{Scheme 36}

Agrofoglio et al. ${ }^{40}$ have developed a strategy to prepare 5-(2-furyl) and 5-(2-thiophenyl) acyclo-nucleosides $\left(\mathbf{8 9}, \mathrm{R}^{1}=\right.$ acyclic diol, $\left.\mathrm{R}^{2}=\mathrm{R}^{3}=\mathrm{H}\right)$ from 5-iodouracil. They used a catalytic system $\left(\mathrm{Pd}(\mathrm{OAc})_{2} \mathrm{AsPh}_{3}, \mathrm{~K}_{2} \mathrm{CO}_{3}\right.$ in THF) to introduce the aryl moiety and the products were obtained in good yields (68-94\%). The synthesis with an alkenyl boronic acid $\left(\mathrm{RCH}=\mathrm{CH}_{2} \mathrm{~B}(\mathrm{OH})_{2}\right)$ was also tested (52-60\%); however, the competition with a Heck reaction led to a mixture of isomers impossible to separate.

More recently, Pomeisl et al. employed the same approach to synthesize 5-aryl-1-(2phosphomethoxy)ethyl uracil $\left(\mathbf{8 9}, \mathrm{R}^{1}=\mathrm{CH}_{2} \mathrm{CH}_{2} \mathrm{OCH}_{2} \mathrm{P}(\mathrm{O})(\mathrm{OR})_{2}, \mathrm{R}^{2}=\mathrm{R}^{3}=\mathrm{H}\right)$ with 
244 moderate isolated yield (24-58\%) using the boronic acids of 1-naphtyl, 2-phenylvinyl,

245 4-fluorophenyl, 3-nitrophenyl, 2-furyl, phenyl, 3- and 4-pyridyl. ${ }^{41}$

As part of a study within the development of labeled PNA, Oquare and Tay247 lor used a Heck reaction to prepare (E)-3-(1-(2-t-butoxy-2-oxoethyl)-2,4-dioxo-1,2,3,4tetrahydropyrimidin-5-yl)acrylic acid (91) from 1-(2-t-butoxy-2-oxoethyl)-5-iodouracil (90) (Scheme 37). ${ }^{42}$ This reaction was a key step in a synthesis of a PNA monomer derived from uracil, produced in 6 steps and 30\% overall yield from commercial 5-iodouracil.

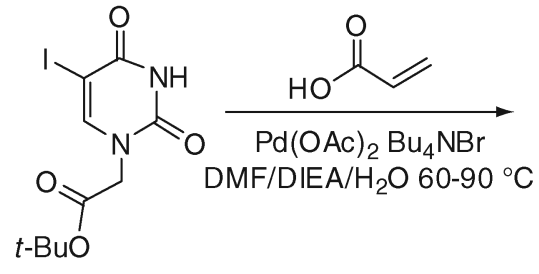

90<smiles>CC(C)(C)OC(=O)Cn1cc(/C=C/C(=O)O)c(=O)[nH]c1=O</smiles>

$91(54 \%)$

Scheme 37

The synthesis of 5-bromoacetyl uracils $\mathbf{9 3}$ from $\mathbf{9 2}$ has been accomplished in $40 \%$ yield (Scheme 38) using a Stille reaction. The ultimate goal was the synthesis of 5-thiazolyl uracils from 93 derivatives, but somewhat surprisingly, the yield of this transformation was not reported. ${ }^{8}$

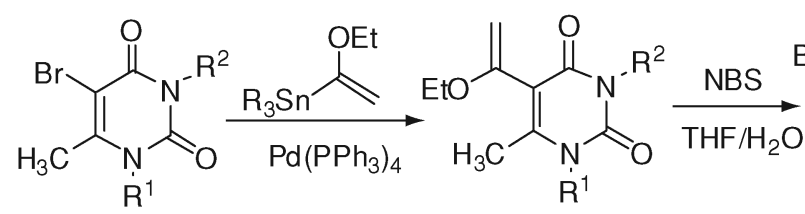
92<smiles>[R7]n1c(C)c(C(=O)CBr)c(=O)n([R7])c1=O</smiles>

$93(40 \%)$

Scheme 38

Mintas et al. have also used this strategy to prepare 5-aryl and 5-alkenyl uracils substituted with a derivative of L-ascorbic acid at N1 ${ }^{43}$ They utilized tributylstannanes to obtain compounds 94 in 31-43\% yield (Scheme 39 ).<smiles>[R]c1cn(C/C=C2/OC(=O)C(Oc3ccccc3)C2Oc2ccccc2)c(=O)[nH]c1=O</smiles>

Scheme 39 
6-Aryl and 6-acyl uracils were recently synthesized from the commercially available 6chloro-2,4-dimethoxypyrimidine (95). ${ }^{5}$ The photostimulated reaction of 95 with the anion ${ }^{-} \mathrm{SnMe}_{3}$ in liquid ammonia afforded stannane 96 in high yield through a $\mathrm{S}_{\mathrm{RN}} 1$ reaction. ${ }^{44}$ Compound 96 was employed in a Stille reaction with 1-iodonaphthalene affording pyrimidine 97 in good yields. Finally the target uracil 98 was obtained by hydrolysis in quantitative yield (Scheme 40).

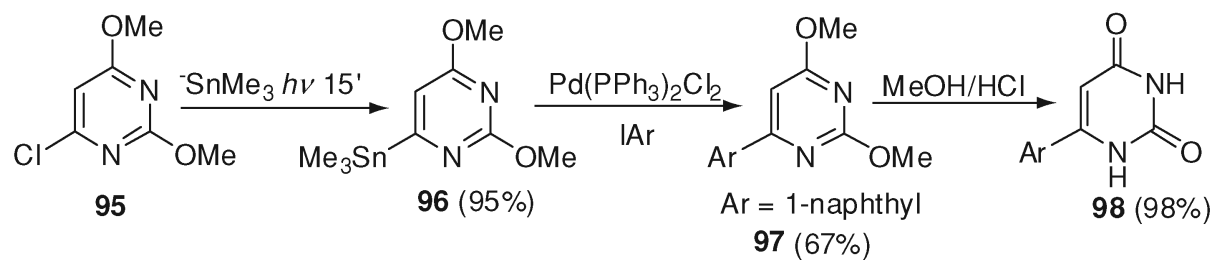

\section{Scheme 40}

When the three steps $\left(\mathrm{S}_{\mathrm{RN}} 1\right.$ reaction-cross coupling reaction-hydrolysis) were performed in a one-pot reaction without the need to purify intermediates 96 and 97 (Scheme 41), 6-substituted uracils 99 ( $\mathrm{R}=$ 1-naphthyl, 4-chlorophenyl, 3-chlorophenyl, 2,3,4,5,6pentafluorophenyl) were obtained $(43-57 \%)$ in isolated pure products. When the electrophile was a benzoyl chloride $(\mathbf{9 9}, \mathrm{R}=\mathrm{ArCO}), 6$-benzoyl (54\%) and 6-(2-chlorobenzoyl) uracils $(49 \%)$ were obtained as isolated pure products.

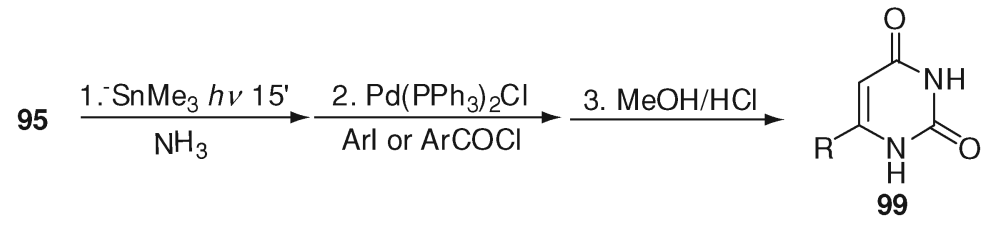

\section{Scheme 41}

Koroniak et al. have synthesized pentafluoropropenyl uracils using an additionelimination approach. ${ }^{45}$ The (2,4-dimethoxypyrimidin-5-yl)lithium compound derived from 100 allowed the preparation of 5-pentafluropropenyl-2,4-dialkoxypyrimidine ( $E$ and $Z$ mixture, 101) by reaction with commercial hexafluoropropene. Substitution on position 6 was possible from $101(\mathrm{R}=\mathrm{Et})$ instead of 100, to give 5,6-dipentafluropropenyl-2,4diethoxypyrimidine; however, the yield was low (43\%). Compound $101(\mathrm{R}=t$-butyl) after hydrolysis gave uracil 102 in good yields (Scheme 42).

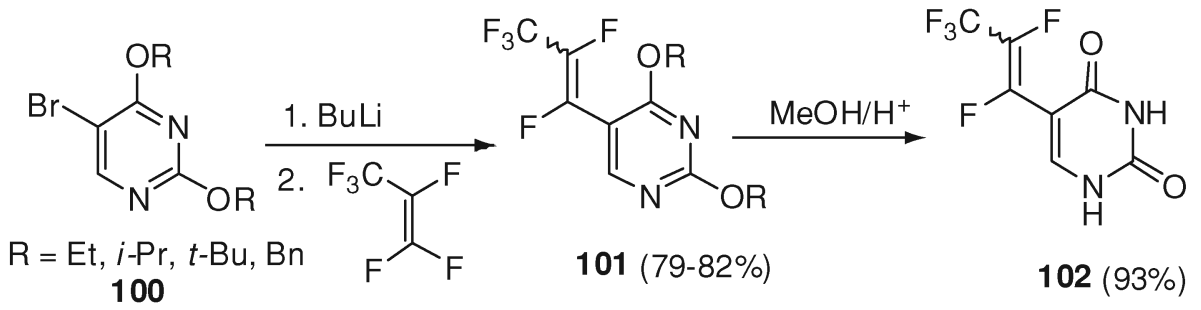

Scheme 42 
From 1,3-dimethyl-5-substituted uracils (103) the authors were able to prepare 6pentafluorouracil (104) with 47-59\% yield for X $=\mathrm{F}$, Me (Scheme 43$)^{45}$ but the reactions were not general, because no products were obtained from addition-elimination when $\mathrm{X}=$ $\mathrm{H}, \mathrm{Br}, \mathrm{NO}_{2}$.<smiles>[X]c1cn(C)c(=O)n(C)c1=O</smiles>

103

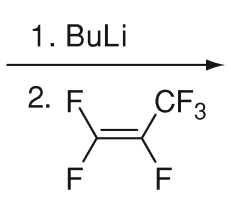

$$
104 X=F(59 \%) ; M e(47 \%)
$$

Scheme 43

Savéant et al ${ }^{46,47}$ have synthesized 5-aryluracils (106) by the reaction of uracil anion (105) with aryl iodides, using an electrochemical approach (Scheme 44, see also Scheme 26). The reactions were postulated to occur through an $\mathrm{S}_{\mathrm{RN}} 1$ reaction and the yields were moderate, where 1-imidazolyl and benzene compounds with $\mathrm{NO}_{2}, \mathrm{CN}, \mathrm{COPh}, \mathrm{CF}_{3}, \mathrm{~F}$ as substituents were introduced.

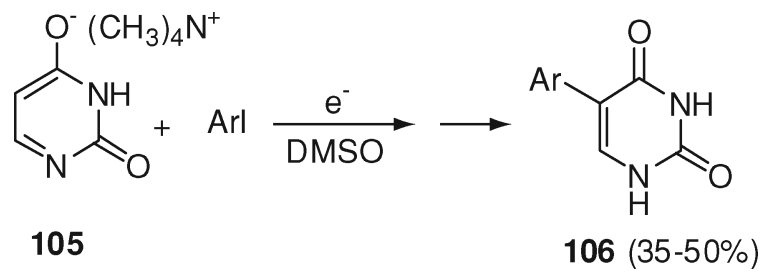

Scheme 44

Using another electrochemical reaction Davarani et al. ${ }^{48}$ have recently synthesized catechol-uracil derivatives (109) in very good yields from 6-aminouracils $\mathbf{1 0 7}$ and catechols 108 (Scheme 45). The reactions proceed through an electrochemical oxidation of catechols followed by a Michael addition and were regioselective, giving only substitution in position 4 of the catechols.

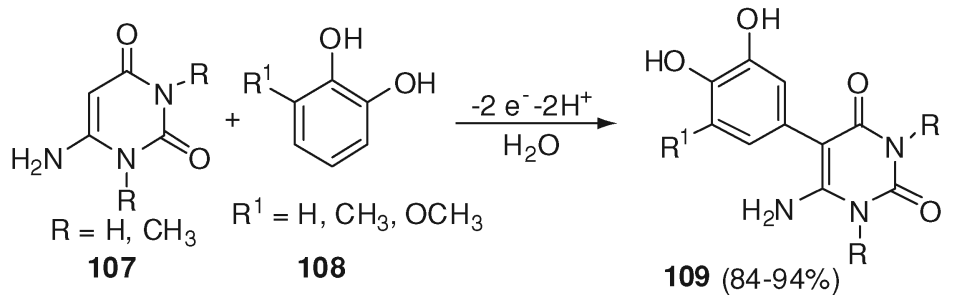

Scheme 45 


\section{3. $C$ (Uracil)-C(sp) Bonds}

The Sonogashira coupling of terminal alkynes has been used to obtain modified nucleosides. ${ }^{49,50}$ Recently, Hudson et al. ${ }^{51,52}$ adopted this approach to prepare 5-alkynyl derivatives with an ester group at N1 or as part of a PNA monomer (Scheme 46). The authors were able to prepare compounds $\mathbf{1 1 0}$ from 5-iodouracil in modest yield (38-53\%) through the reaction of different alkynes. The synthesis also was performed with the uracil-PNA unit linked to an insoluble polymer support. ${ }^{51}$
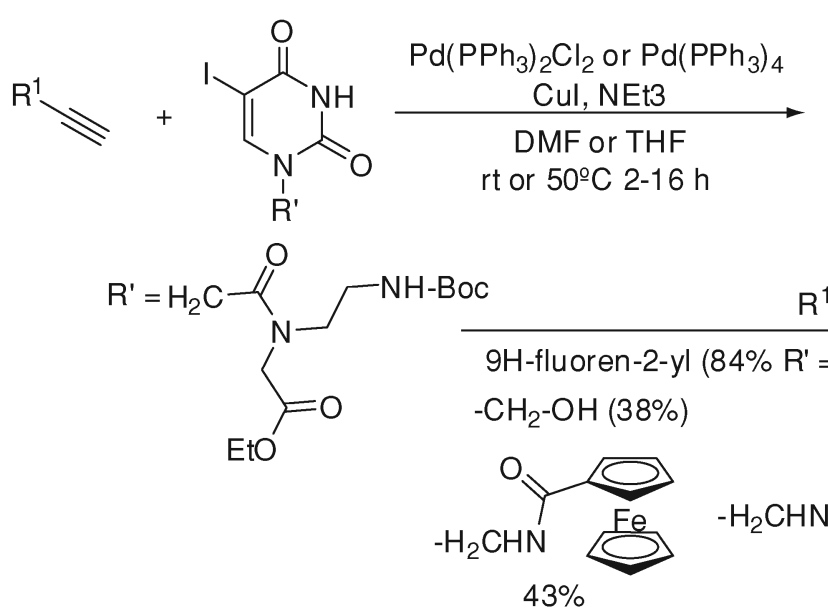

$43 \%$

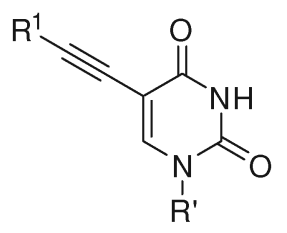

110$$
\mathrm{R}^{1}
$$

$\mathrm{R}$

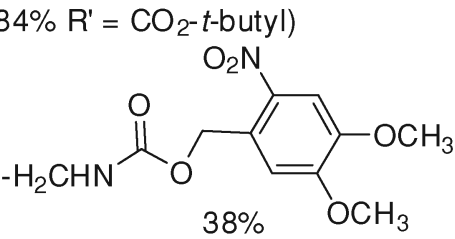<smiles>COc1ccc(Cc2ccccc2)cc1</smiles>

$53 \%$

Scheme 46

Under similar experimental conditions, Mintas et al. reported the synthesis of fourteen 5-alkynyl nucleoside analogues (111) in moderate to good yield from $(Z)$ - and $(E)$-1-[4'( $N$-phthalimido)-2'-butenyl]-5-iodouracil (Scheme 47). ${ }^{53}$<smiles>C=C1NC=C(I)C(=O)N1</smiles>

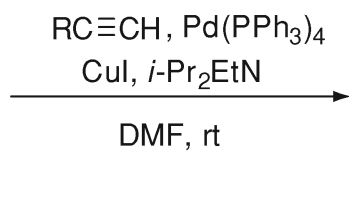

$$
\begin{aligned}
\mathrm{R}= & -\left(\mathrm{CH}_{2}\right)_{3} \mathrm{CH}_{3},-\left(\mathrm{CH}_{2}\right)_{4} \mathrm{CH}_{3},-\left(\mathrm{CH}_{2}\right)_{5} \mathrm{CH}_{3},-\left(\mathrm{CH}_{2}\right)_{7} \mathrm{CH}_{3} \\
& -\left(\mathrm{CH}_{2}\right)_{2} \mathrm{Ph}, 4-\mathrm{PhBr}, 4-\mathrm{PhCH} \mathrm{H}_{3}, 4-\mathrm{Ph}\left(\mathrm{CH}_{2}\right)_{3} \mathrm{CH}_{3}, 4-\mathrm{Ph}\left(\mathrm{CH}_{2}\right)_{4} \mathrm{CH}_{3}
\end{aligned}
$$

\section{Scheme 47}

300

The Stille reaction has been also used by Mintas et al. to prepare 5-alkynyl derivatives. ${ }^{43}$ They employed a set of tributylstannanes to prepare compounds $112(\mathrm{R}=\mathrm{H}(44 \%), \mathrm{R}=$ Me (33\%) yields, Scheme 48). 


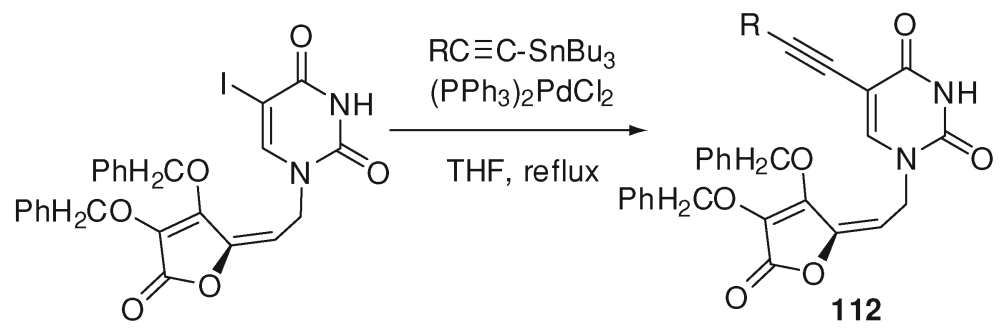

Scheme 48

\section{C(Uracil)-Heteroatom Bonds}

\section{a. $C$ (Uracil)-N Bonds}

Uracils linked to amines are perhaps the most studied heteroatom-substituted derivatives due to the fact that many synthetic and natural compounds of this type exhibit a diverse range of biological activities. The synthesis of 6-aminouracils from condensation of 2cyano acetic acid with urea and $N$-alkylureas was developed by Traube in 1900 , but the reaction times were long and the yields poor. Recently, Devi and Bhuyan have improved this synthesis by performing the reaction without solvent under MW irradiation, obtaining good yields of 6-aminouracils (Scheme 49). ${ }^{54}$

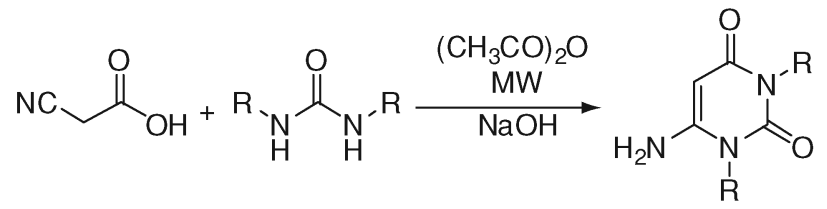

$(63-80 \%)$

\section{Scheme 49}

Although, the synthesis of many 6- and 5-( $N$-substituted) uracils has been developed in the 1970s, ${ }^{55,56}$ Wright and co-workers synthesized 6-(3-ethyl-4-methylanilinyl)3-alkyluracils (114) using a modified method from 6-amino pyrimidinone (113) with good yields (Scheme 50). Concomitant deprotection of the imido group happened to give uracil directly. ${ }^{57}$

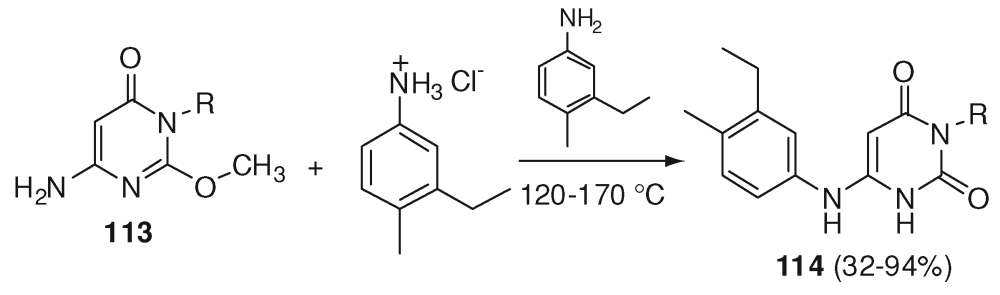

Scheme 50

With a similar approach Spiccia et al. ${ }^{58}$ have recently synthesized a PNA monomer attached to a ferrocenyl moiety. From dimethyl(ferrocenyl-methyl) ammonium salt 115, the reaction with 5-aminouracil, uracil 116 was obtained in good yield (Scheme 51). From 


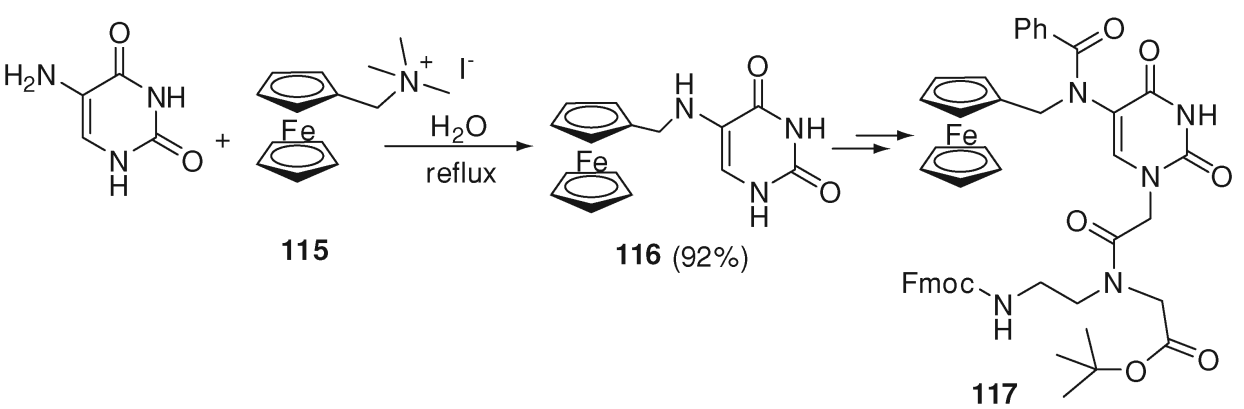

Scheme 51

this compound the authors could prepare PNA monomer 117 (15\% from 115) and analyzed its electrochemical properties.

In a detailed study of the reaction of 6-chlorouracils with pyridines and 1methylimidazole, Schmidt and Kindermann synthesized uracilates, uracilium salts 118, and uracilylbetaines 119 (Figure 3). ${ }^{59}$ Reaction of 6-chloro-1,3-dimethyluracil with both heterocycles produced uracilium salts 118 in good yield (65-67\%); derivatives of pyridine 18a could be isolated with different anions $\left(\mathrm{X}=\mathrm{Cl}, \mathrm{BPh}_{4}, \mathrm{SbCl}_{6}, \mathrm{I}\right.$, OTf).

The use of 6-chloro-3-methyluracil could give mesomeric uracil betaines $119(58-79 \%)$ for the reaction with the same amines (Figure 3). The reaction of 119 with 1,2dichloroethane afforded 1,1'-(3,3'-(ethane-1,2-diyl)bis(1-methyl-2,6-dioxo-1,2,3,6-tetrahydropyrimidine-4,3-diyl))bis(4-(dimethylamino)pyridinium) (Figure 4) in 88\% yield.

\section{b. Synthesis of 5,6-Halogen Derivatives}

In many cases, halogens as substituents in uracil derivatives lead to interesting biological activity and/or improved biological properties. Additionally, most of the substitution on the uracil nucleus is performed by substitution of the halogen on 5- or 6- (or 5,6-) halouracils by different functional groups. For this reason, various syntheses of 5- and 6-halogen uracils have been studied and the search for better conditions is of current interest. 5and 6-Halogenuracils have been synthesized by $\mathrm{I}_{2} /$ nitric acid, $\mathrm{ICl}, \mathrm{Br}_{2} /(\mathrm{AcO})_{2} \mathrm{O}, \mathrm{Br}_{2} / \mathrm{H}_{2} \mathrm{O}$, $\mathrm{Br}_{2} / \mathrm{DMF}, \mathrm{Cl}_{2}$, NXS, CAN/halogen source, among others. ${ }^{60-62}$

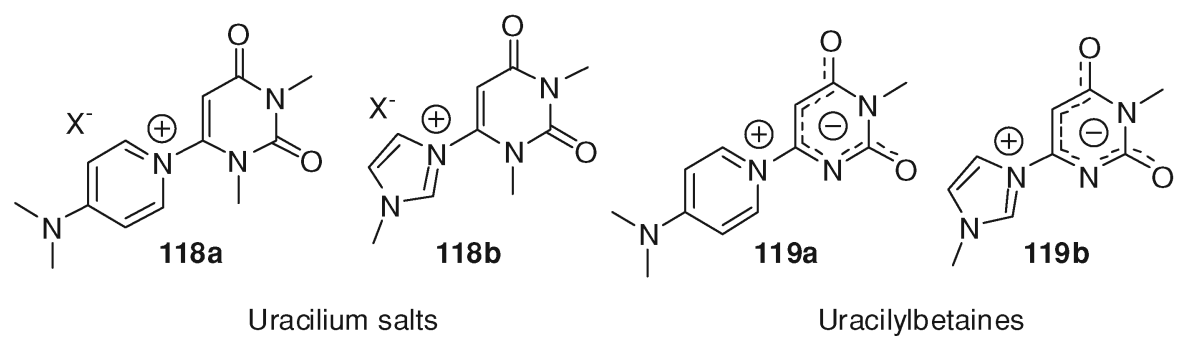

Figure 3 


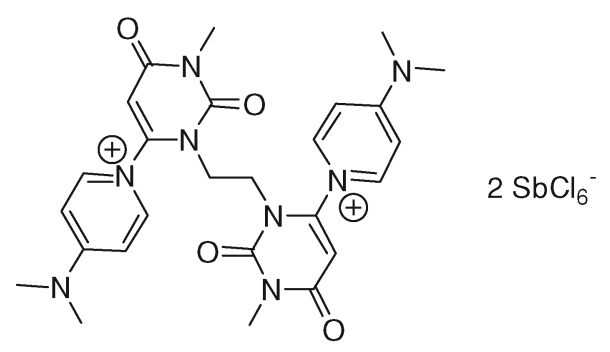

Figure 4

340 Recently, in a search for a more friendly approach to the iodination of pyrimidine341 2,4-diones, Botta et al. synthesized 5-iodouracils from uracils (Scheme 52). ${ }^{63}$ With $\mathrm{N}$ 342 iodosuccinimide (NIS) as the iodine source and three minutes MW irradiation, excellent 343 yields of substitution products (97-98\%) were obtained. The use of an unprotected nucleo344 side gave a yield of $65 \%$. The authors tested the methodology in solid-supported chemistry 345 and obtained good results, demonstrating the applicability of solid-phase organic synthesis for pyrimidones and nucleosides.<smiles></smiles>

Using the methodology described in Section I.1 (Scheme 25), Kopp and Knochel also prepared 5-pheny(methyl)sulfanyluracil and 5-trimethylsilyluracil in good yields (64-77\%). ${ }^{26}$ Doung and Louie (Section I.1, Scheme 14) synthesized 5-trimethylsilyl-6-alkyl-1,3aryluracils with variable yields $(17-83 \%) .{ }^{21}$ Suemune et al. (Section I.1, Scheme 20) have synthesized 5-trimethylsilyl- and 5-(methylthio)-2'-deoxyuridine in good yields $(62-85 \%) .^{23}$

354

355

356

357

358

359

360

361

362

\section{Fused Systems}

\section{C5-C6 Polycyclic Uracils}

In a search for new uracils, Botta and Saladino et al. have synthesized fused pyrazole derivatives, through the reaction 5- and 6-substituted uracil with lithium trimethylsilyldiazomethane TMSC(Li)N 2 (121) or diazomethane. ${ }^{64,65}$ The authors used N1,N3-alkylated uracils and N3-alkylated uridines and found umpolung of reactivity of $\mathbf{1 2 1}$ in reaction with C6 derivatives.

When unsubstituted or 5-fluorouracils $120(X=\mathrm{H}, \mathrm{F} ; \mathrm{Y}=\mathrm{H})$ were allowed to react with 121, products 122 were obtained in good yield (Scheme 53); the formation of the 


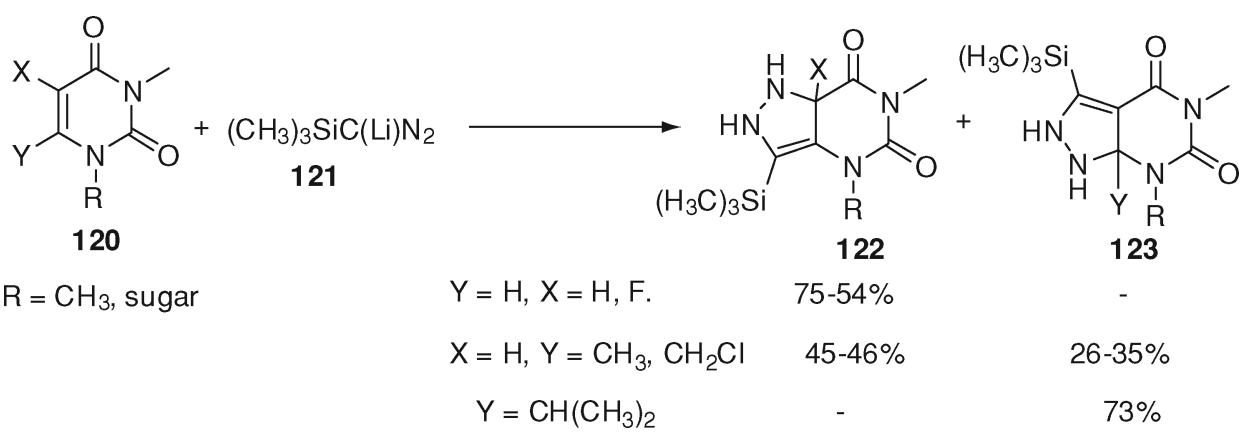

Scheme 53

products is attributed to nucleophilic attack at $\mathrm{C} 6$ and subsequent cyclization. When $\mathrm{X}$ $=\mathrm{NO}_{2}, \mathrm{CN}$ or $\mathrm{CHO}$, poor yields or no cyclic product 122 were obtained; however, in the case of the nitro compound using diazomethane instead of $\mathbf{1 2 1}$ gave an acceptable yield $(39-45 \%)$ of 3a,7a-dihydro-4,6-dimethyl-7a-nitro- $\Delta^{1}$-pyrazolino[4,3-d]pyrimidin5,7-dione regioisomer analogue to $\mathbf{1 2 2}$.

With C6 substituted uracils $(\mathbf{1 2 0}, \mathrm{X}=\mathrm{H})$, the reaction with $\mathbf{1 2 1}$ gave a mixture of $\mathbf{1 2 2}$ and pyrazolidine $\mathbf{1 2 3}$ (Scheme 53), due to attack of $\mathbf{1 2 1}$ to C5 instead of C6. The use of an isopropyl group at $\mathrm{C} 6$ allowed the preparation of $\mathbf{1 2 3}$ in good yield without the formation of $\mathbf{1 2 2}$.

The reaction with halogen (other than fluorine) was only successful when $\mathrm{X}=\mathrm{Br}$, giving fused uracil derivatives $\mathbf{1 2 4}$ after loss of hydrogen bromide (Scheme 54).

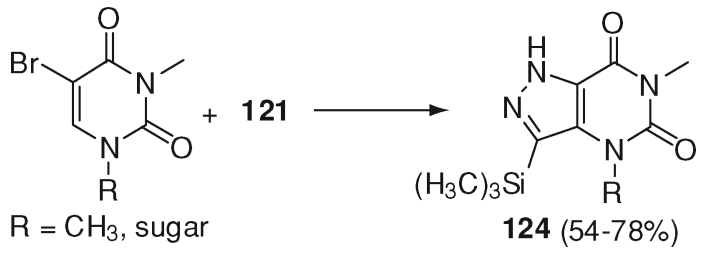

\section{Scheme 54}

Bhuyan and co-workers have synthesized various complex fused uracils by means of different approaches. ${ }^{66-68}$ From $\mathrm{N}, \mathrm{N}$-dimethyl-5-formylbarbituric acid or 6amino-1,3-dimethyluracil (125), pyrano-(126a) and pyrido[2,3- $d$ ]pyrimidine (126b) and (thio)oxazino[4,5d]pyrimidine (127a and $\mathbf{1 2 7}$ ) $)$ were prepared through a MW- assisted solid-phase (Scheme 55). Using maleimide or phenyl isothiocyanate as dienophiles, the authors showed that MW-assisted reactions gave better yields than conventional thermal reactions. ${ }^{66}$

More recently, access to fused-spiro uracils (129) from 6-( $N, N$-dialkylamino)-5formyluracil (128) and barbituric acids was demonstrated (Scheme 56). ${ }^{67}$

A hypothetical mechanism was proposed but poorly demonstrated: after Knoevenagel condensation to give product 128a an internal redox process occurred to generate a 1,6dipole through a $1,5-\mathrm{H}$ shift. Cyclization of the zwitterion formed gave the final product (Scheme 57). 


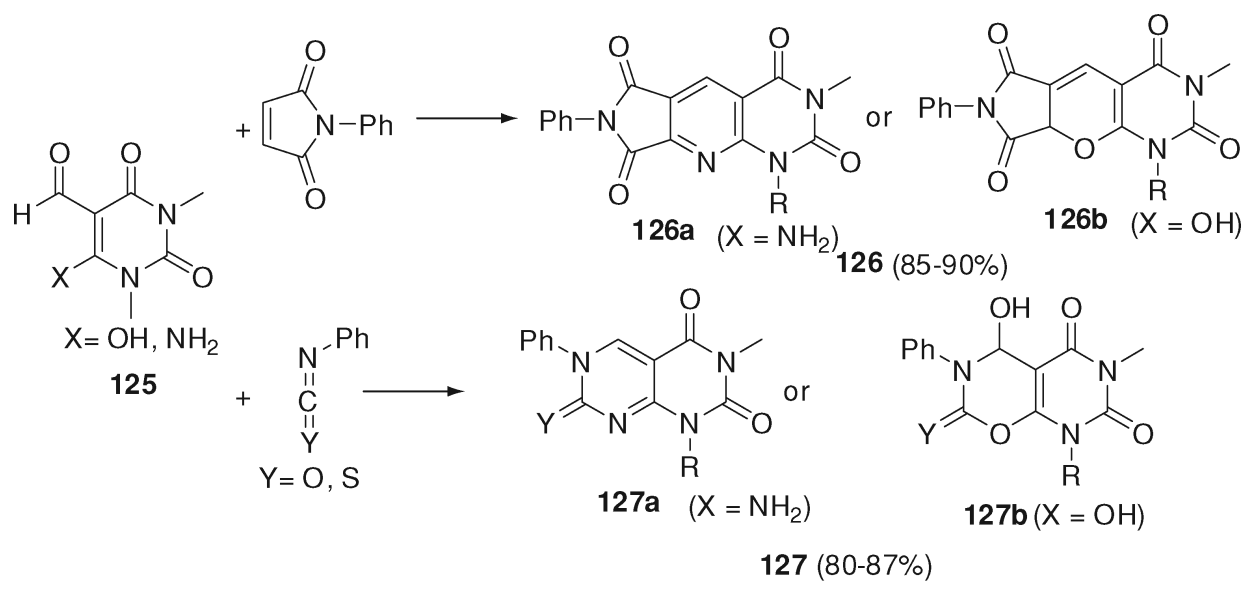

Scheme 55

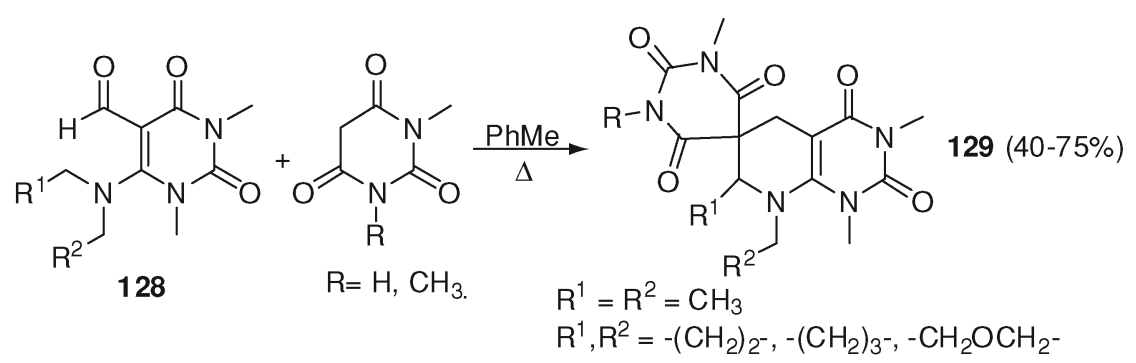

Scheme 56

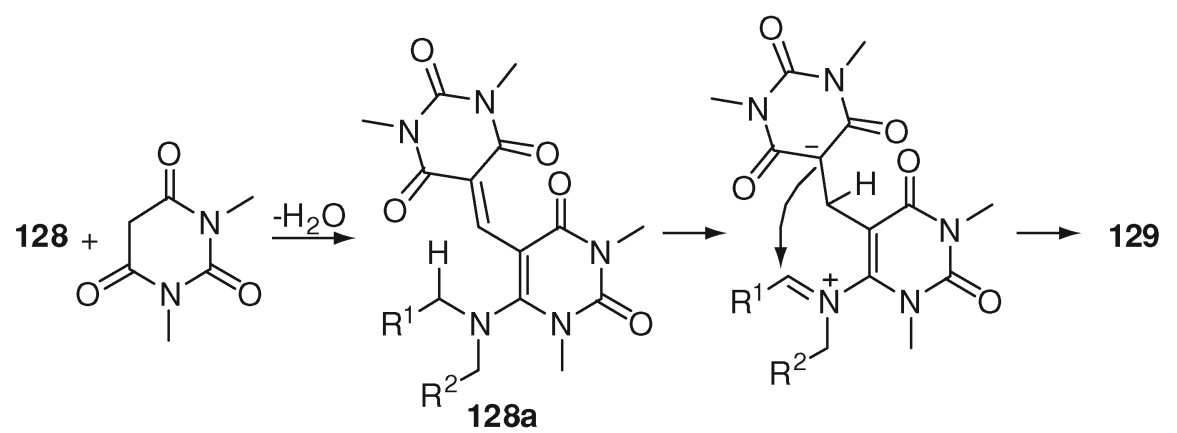

Scheme 57

A stereoselective intramolecular hetero Diels-Alder reaction of compound $\mathbf{1 3 0}$ (Scheme 58), prepared from barbituric acids and salicylaldehyde, allowed the preparation of the fused system 131 in good yield with less than $5 \%$ of the trans-stereoisomer. ${ }^{68}$

A similar approach was used by Gross et al. ${ }^{69}$ to prepare $\mathbf{1 3 3}$ in very good yields (Scheme 59) from 1,3-dimethyl barbituric acid and aldehydes 132. A domino Knoevenagelhetero-Diels-Alder reaction was used and although a catalytic amount of $\mathrm{CuI}$ is required to activate the alkyne, the reactions have the advantage of using water as solvent.

An intermolecular variation of this hetero-Diels-Alder reaction was used to prepare pyrano[2,3- $d$ ] pyridine-2,4-dione 137 from 5-arylidene-1,3-dimethylbarbituric acid $\mathbf{1 3 6}$ and 
<smiles>[R2]N1C(=O)C(=Cc2ccccc2OCC=C)C(=O)N([R7])C1=O</smiles>

130<smiles>C[Mg]P(C)O</smiles>

$\mathrm{R}^{1}, \mathrm{R}^{2}=\mathrm{H}, \mathrm{CH}_{3}$<smiles>[R7]n1c2c(c(=O)n([R7])c1=O)[C@@H]1c3ccccc3OC[C@H]1CO2</smiles>

$131(65-75 \%)$

\section{Scheme 58}

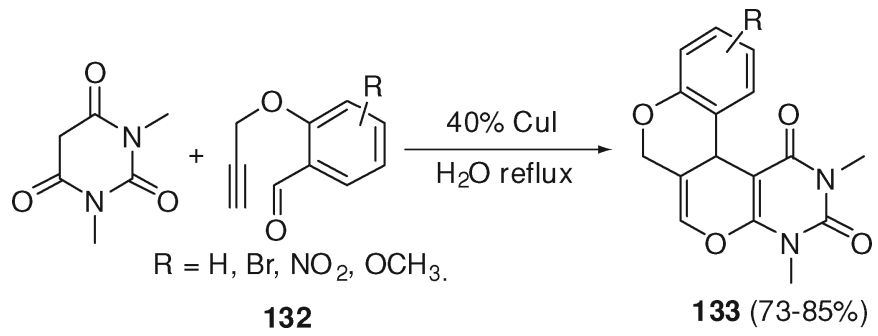

Scheme 59

enol ethers 135. The goal of the authors was to prepare compounds 137 via a threecomponent one-pot synthesis, as shown in Scheme 60, giving the desired products in excellent yields. $^{2}$

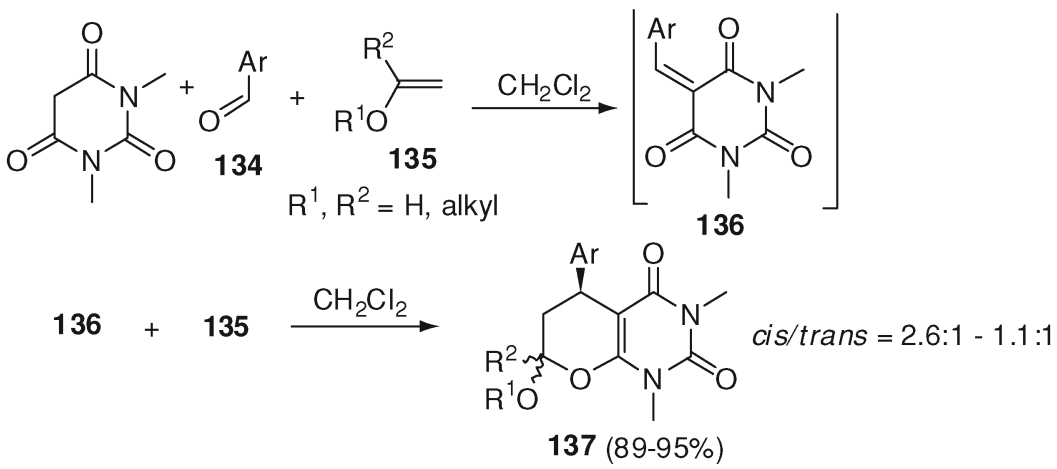

\section{Scheme 60}

Pyrano[3,2-c]pyrimidines-2,4-diones (139) have been synthesized in excellent yields (92-100\%) via Pd-catalyzed reaction from 5-substituted-1,3-dimethyuracils (138) (Scheme 61). ${ }^{70}$ The proposed mechanism involves an uncommon [1,3]aryloxy migration, followed by a 6-endo dig cyclization.

Using the same methodology described in Section I.1.a, (Scheme 28), Fustero and co-worker synthesized the 5,6-disubstituted uracils 140a in order to prepare C5-C6 fused uracils 141 through an intramolecular olefin metathesis (Scheme 62). ${ }^{71}$ Compound 141a 


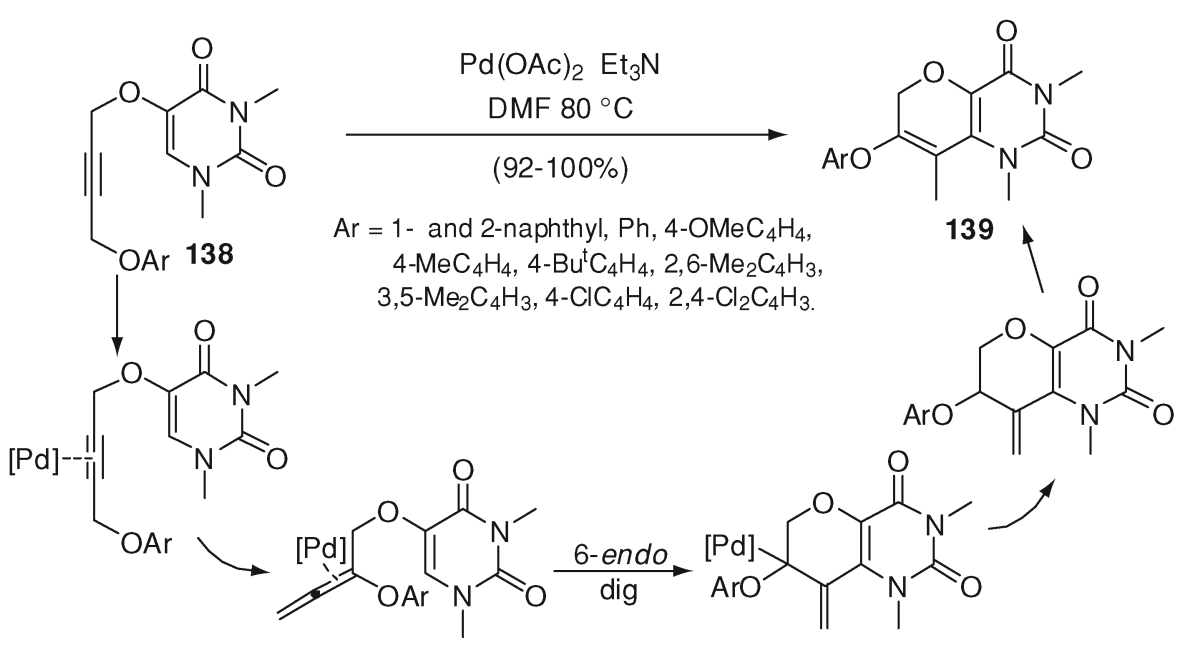

Scheme 61

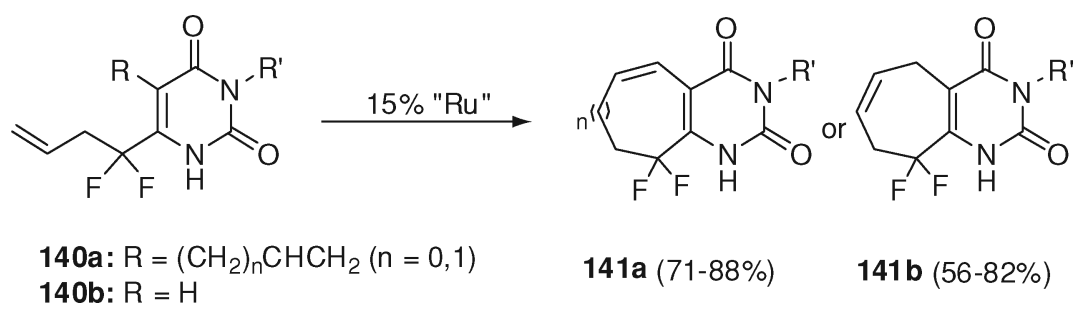

Scheme 62

was obtained for $\mathrm{n}=0$ but by using different Ru catalysts the authors could control, the reaction obtaining 141a $(\mathrm{n}=1)$ or $141 \mathrm{~b}$ as a single product from 140a $(\mathrm{n}=1)$.

As shown in Scheme 63, the preparation of N1-C6 fused-uracils 142 was also possible from 140b.

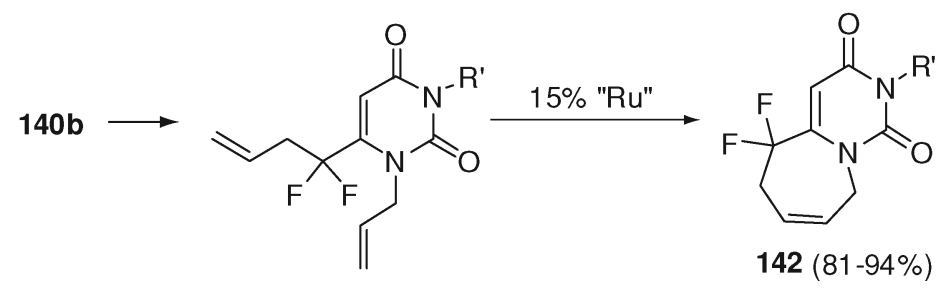

Scheme 63

Through a well-known Pd-catalyzed arylation, Woodward et al. have synthesized uracils fused to a phenyl group in good yields from reaction of 2-bromobenzoic methyl esters (143) and substituted ureas (144) (Scheme 64). ${ }^{72}$ Both electron-donating as well as electron-withdrawing substituents in the phenyl moiety are tolerated. In addition, a regioselective reaction was obtained with monosubstituted ureas $144\left(\mathrm{R}^{1}=\mathrm{H}\right)$ to obtain N3 alkyl uracils $145\left(R^{1}=H\right)$.

From substituted phenylamines, Rivkin et al. ${ }^{73}$ prepared analogues of $\mathbf{1 4 5}$, mono and disubstituted in the phenyl ring, using bis(pentafluorophenyl) imidodicarbonate (146) in a 
<smiles>COC(OC)c1ccccc1Br</smiles>
143<smiles>[R]NC(=O)N[Tl]</smiles>

$\mathrm{R}^{1}=\mathrm{H}, \mathrm{CH}_{3}$ $\mathrm{R}^{2}=$ alkyl, allyl, $\mathrm{Ph}$ 144

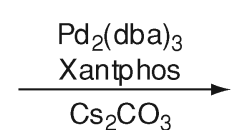
Dioxane $100 \stackrel{\circ}{\circ}$

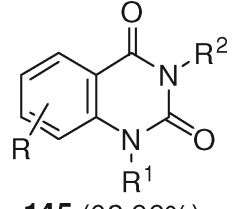

$145(62-99 \%)$

Scheme 64

solvent-free MW reaction; the yields were moderate to good (44-78\%). The use of other heteroaromatic amines (147) allowed the authors to prepare compound 148 in moderate yield (Scheme 65). The synthesis of one disubstituted uracil was carried out from (2E)-3amino-3-(4-bromophenyl)acrylonitrile in $84 \%$ yield.

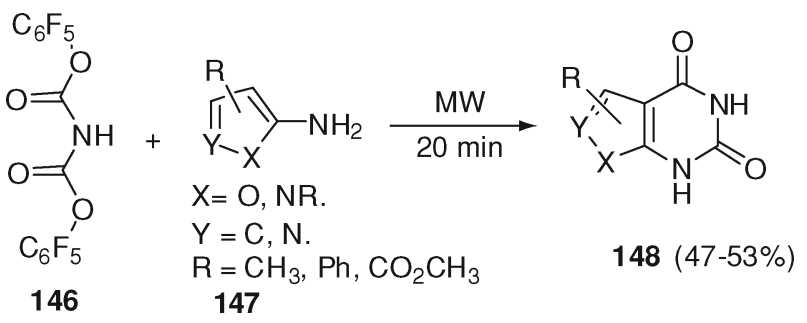

\section{Scheme 65}

Xanthine (151a) or pteridine (151b) derivatives were obtained in moderate to good yields from 5,6-diamino-1,3-dimethyluracil (149). The synthetic sequence involves the preparation of enamines 150 from aldehydes and subsequent reaction with different onecarbon sources (triethyl orthoformate, orthoacetate or orthobenzoate). Depending on the ortho ester used, 151a or 151b was obtained (Scheme 66). ${ }^{74}$

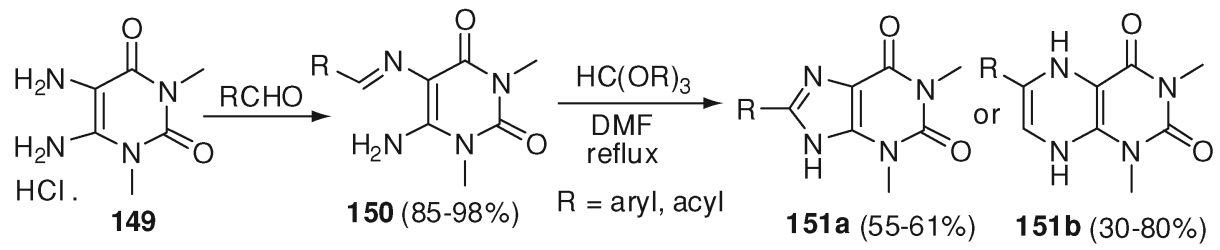

\section{Scheme 66}

Spiro[pyrimido-[4,5-d]quinoline-5,5'-pyrrolo[2,3-d]pyrimidine]pentanones were synthesized by Bazgir et al. from 6-aminouracils (152) and 5-substituted indoline2,3-diones (153) (Scheme 67), using water as solvent and 4-toluenesulfonic acid (4-TSA) as catalyst. The complex polyheterocyclic compounds $\mathbf{1 5 4}$ were obtained in very good yields $(78-90 \%){ }^{75}$

Although a mechanism could not be established with certainty, a possible route was proposed as depicted in Scheme 68.

It has been shown that the replacement of one carbon atom by nitrogen is a good strategy to obtain new potential antitumor compounds from known anticancer drug. ${ }^{76-78}$ 
<smiles>[R]n1c(=O)cc(N)[nH]c1=O</smiles>

$R^{1}, R^{2}=H, M e$

152<smiles>[X]c1ccc2c(c1)C(=O)C(=O)N2</smiles>
$\mathrm{X}=\mathrm{H}, \mathrm{Br}, \mathrm{NO}_{2}$ 153<smiles>[X]c1ccc2c(c1)C1(C(=O)NC3C1C(=O)N([R])C(=O)N3[R])c1c([nH]c(=O)n([R7])c1=O)N2</smiles>

$154(78-90 \%)$

Scheme 67<smiles>[X]c1ccc2c(c1)C(O)(c1c(N)[nH]c(=O)n([R7])c1=O)C(=O)N2</smiles>

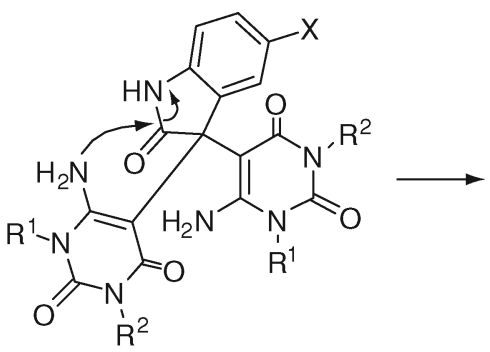

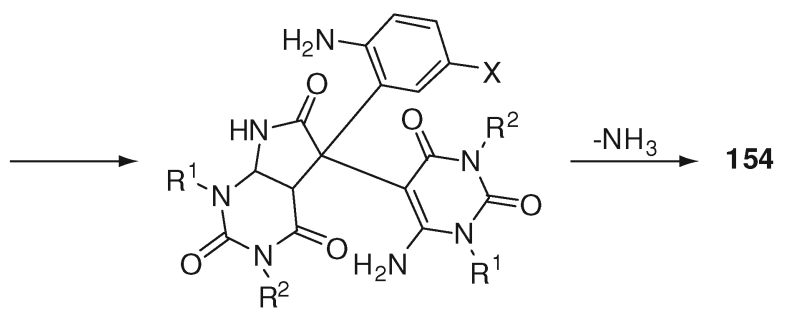

Scheme 68

In line with this, Valderrama and Vásquez proposed the synthesis of $a z a$-analogues of angucyclinone (Figure 5).

The authors synthesized quinones $\mathbf{1 5 6}$ in good yields from hydroquinone $\mathbf{1 5 5}$ and 6-amino-1,3-dimethyluracil using $\mathrm{Ag}_{2} \mathrm{O}$ in $\mathrm{CH}_{2} \mathrm{Cl}_{2}$ at room temperature (Scheme 69). ${ }^{79}$

From compounds 156, adducts 157 and 158 (Figure 6) were synthesized through a cycloaddition reaction with different dienes. Angucyclinone 159 analogues from 157 were finally obtained with good yields by mild hydrolysis with hydrochloric acid followed by oxidation with PCC of the alcohol intermediaries.<smiles>O=C1c2cccc(O)c2C(=O)c2c1ccc1c2C(=O)CCC1</smiles>

Figure 5 


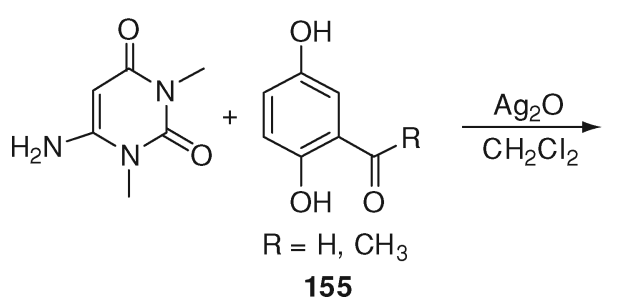<smiles>[R]c1nc2c(c3c1C(=O)C=CC3=O)c(=O)n(C)c(=O)n2C</smiles>

\section{Scheme 69}

Using the versatile diazo compound 29 (see Scheme 34), Vasella et al. have also prepared different fused uracils through a $\mathrm{Rh}(\mathrm{II})$-promoted reaction with different carbenophiles by an intramolecular reaction. ${ }^{20}$ Thermolysis of 29 in toluene gave 1:1 mixture $1 H$ - and $2 H$-pyrazolo[4,3-d] uracil in 55\% yield after deprotection with $\mathrm{BBr}_{3}$ (Scheme 70).

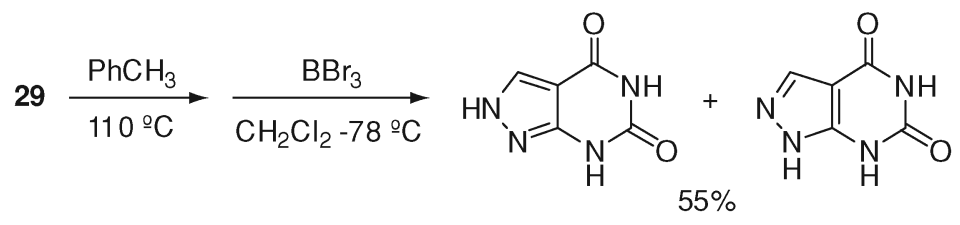

\section{Scheme 70}

The reaction of 29 with 2-methoxypropene in the presence of $\mathrm{Rh}_{2}(\mathrm{AcO})_{4}$ (Scheme 71) gave a cyclopropane derivative (endo/exo) from addition to the double bond, which after treatment with $\mathrm{AlClMe}_{2}$ gave the cyclopenta[d]pyrimidine 160 in $55 \%$ yield. The reaction of dihydrofuran and dihydropyran afforded tricyclic uracils 161 and 162 in $51 \%$ and $88 \%$ yields respectively, through the same reaction sequence. The use of furan gave $\mathbf{1 6 3}$ in $73 \%$ yield without the need of $\mathrm{Al}(\mathrm{III})$ catalysis.

The acid-catalyzed intramolecular cyclization of $\mathbf{8 6}$ prepared from $\mathbf{2 9}$ (see Scheme 35), gave fused-diuracil 164 in $73 \%$ yield (Scheme 72$).{ }^{20}$

\section{Other Polycyclic Uracils}

Uracil derivatives fused at C5-O4 or C6-N1 are less common than the fused uracils previously described; however, some efforts have also been made to develop new synthetic strategies for this family of compounds.

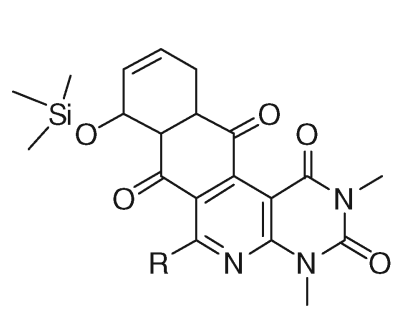

157<smiles></smiles>

158<smiles>[R]c1cccc2c1C(=O)c1c([R])nc3c(c1-2)c(=O)n(C)c(=O)n3C</smiles>

$159 \mathrm{R}^{\prime}=\mathrm{H}, \mathrm{OH}$

Figure 6 


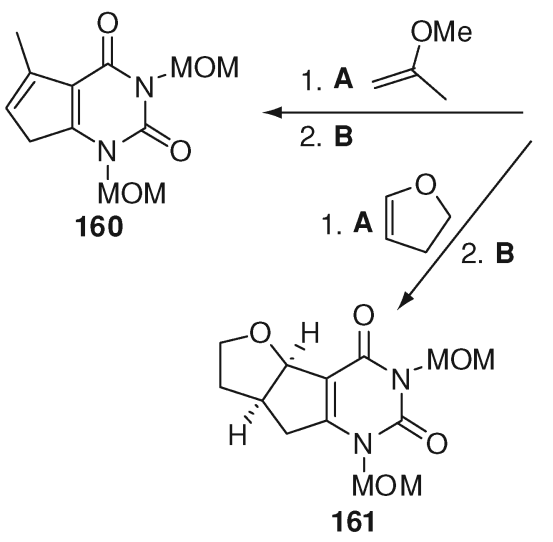

A. $\mathrm{Rh}_{2}(\mathrm{AcO})_{4}, \mathrm{CH}_{2} \mathrm{Cl}_{2}$. B. $\mathrm{AlClR}_{2} \mathrm{CH}_{2} \mathrm{Cl}_{2}$

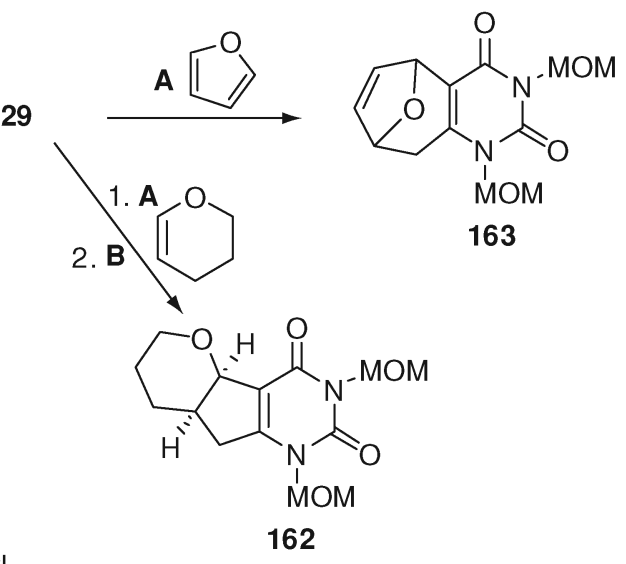

Scheme 71

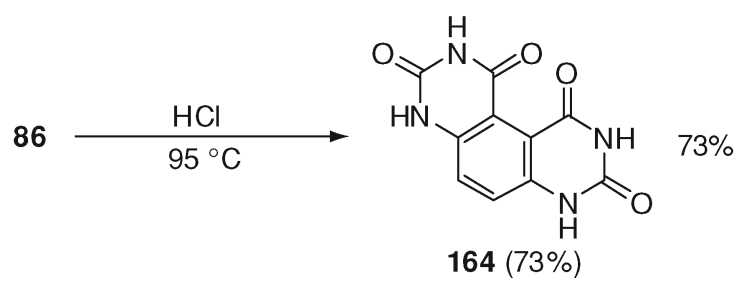

Scheme 72

Robins and co-workers extended their work in the synthesis and the biological evaluation of furo[2,3-d]pyrimidin-2(3H)-one and synthesized derivatives 166 (Scheme 73). ${ }^{80,81}$ N1 substituted uracils were synthesized in moderate to good yields (51-83\%) from 5iodouracils $165\left(\mathrm{R}^{\prime}=\mathrm{CH}_{2} \mathrm{O}\left(\mathrm{CH}_{2}\right)_{2} \mathrm{OH}\right)$, and different alkynes. The authors performed a Sonogashira coupling following a $\mathrm{Cu}(\mathrm{I})$-promoted cyclization in a two step one pot procedure. ${ }^{80}$ The synthesis of free uracil $166\left(\mathrm{R}^{\prime}=\mathrm{H}\right)$ was also done using the same approach, but in two consecutive steps and lower yields (step one 50-80\%, step two 28-34\%).

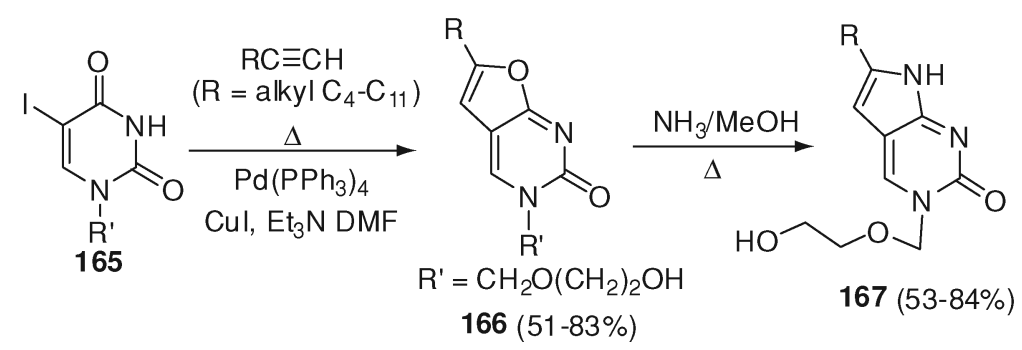

Scheme 73 


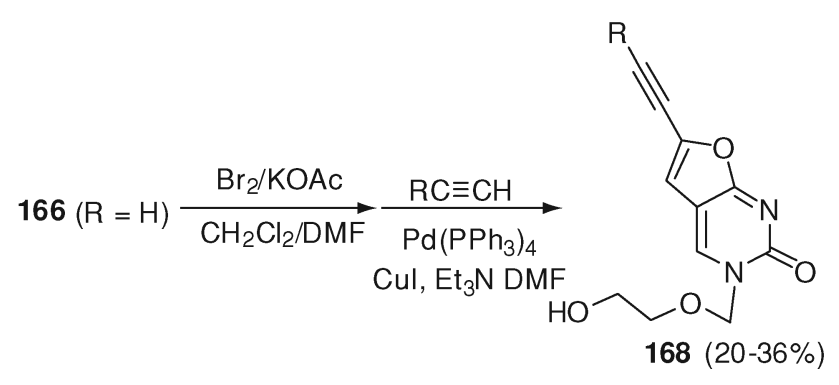

\section{Scheme 74}

Access to pyrrolo derivatives 167 was possible from $166\left(\mathrm{R}^{\prime}=\mathrm{CH}_{2} \mathrm{O}\left(\mathrm{CH}_{2}\right)_{2} \mathrm{OH}\right)$ after treatment with ammonia in methanol (Scheme 73).

Compound $166(\mathrm{R}=\mathrm{H})$ was also synthesized; however, the yield was low (30\%). This compound was used to prepare alkynyl derivatives 168 by performing a bromination and a Sonogashira coupling with different alkynes but again the yields were low (Scheme 74). ${ }^{80}$

\section{Glossary}

Cp: Cyclopenta-2,4-dien-1-ide

DIEA: $N, N$-Diisopropylethylamine

DMA: Dimethylacetamide

DMF: $N, N$-Dimethylformamide

DMSO: Dimethyl sulfoxide

dR: Deoxyuridine

FG: Functional group

LDA: Lithium diisopropylamide

L: Ligand

MW: Microwave

NXS: $N$-Halosuccinimide

PCC: Pyridinium chlorochromate

PNA: Peptide nucleic acid

$\mathrm{S}_{\mathrm{RN}}$ 1: Unimolecular Radical Nucleophilic Substitution

TABF: Tetrabutylammonium fluoride

THF: Tetrahydrofuran

TMSCl: Trimethylchlorosilane

TMS: Trimethylsilyl

TP: Thymidine phosphorylase

MNP: $\left(\mathrm{CH}_{3}\right)_{3} \mathrm{C}-\mathrm{N}=\mathrm{O}$

4-TSA: 4-Toluene sulfonicacid

Xantphos: 2,2'-Oxybis(2,1-phenylene) bis(diphenylphosphine)

\section{Acknowledgements}

This work was supported in part by the Agencia Córdoba Ciencia, the Consejo Nacional de Investigaciones Científicas y Técnicas (CONICET), SECYT, Universidad Nacional de 
499 500

501

Córdoba, and FONCYT, Argentina. J. I. B. gratefully acknowledges receipt of a fellowship from CONICET.

\section{References}

1. M. Lagoja, Chem. Biodiv., 2, 1 (2005).

2. A. Palasz, Monatsh. Chem, 139, 1397 (2008).

3. D. Uraguchi, K. Yamamoto, Y. Ohtsuka, K. Tokuhisa and T. Yamakawa, Appl. Catal., A, 348, 137 (2008).

4. R. Saladino, C. Crestini, A. T. Palamara, M. C. Danti, F. Manetti, F. Corelli, E. Garaci and M. Botta, J. Med. Chem., 44, 4554 (2001).

5. J. I. Bardagí and R. A. Rossi, J. Org. Chem., 73, 4491 (2008).

6. C. B. Reese and Q. Wu, Org. Biomol. Chem., 1, 3160 (2003).

7. Z. Guo, Y. Zhu, F. C. Tucci, Y. Gao, R. S. Struthers, J. Saunders, T. D. Gross, Q. Xie, G. J. Reinhartb and C. Chen, Bioorg. Med. Chem. Lett., 13, 3311 (2003).

8. M. W. Rowbottom, F. C. Tucci, P. J. Connors, Jr., T. D. Gross, Y. Zhu, Z. Guo, M. Moorjani, O. Acevedo, L. Carter, S. K. Sullivan, Q. Xie, A. Fisher, R. S. Struthers, J. Saundersa and C. Chen, Bioorg. Med. Chem. Lett., 14, 4967 (2004).

9. Y. Zhu, T. D. Gross, Z. Guo, P. J. Connors, Jr., Y. Gao, F. C. Tucci, R. S. Struthers, G. J. Reinhart, J. Saunders, T. K. Chen, A. L. K. Bonneville and C. Chen, J. Med. Chem., 46, 2023 (2003).

10. A. Dinsmore, P. M. Doyle, P. B. Hitchcock and D. W. Young, Tetrahedron Lett., 41, 10153 (2000).

11. C. G. Lee, S. Gowrisankar and J. N. Kim, Bull. Korean Chem. Soc., 26, 3, 481 (2005); Chem. Abstr., 143, 440139 (2005).

12. S. Nag, G.P. Yadav, P. R. Maulik and S. Batra, Synthesis, 6, 911 (2007).

13. J. Cao and X. Huang, J. Comb. Chem., 10, 526 (2008).

14. S. Yano, H. Kazuno, N. Suzuki, T. Emura, K. Wierzba, J. Yamashita, Y. Tada, Y. Yamada, M. Fukushima and T. Asao, Bioorg. Med. Chem., 12, 3431 (2004).

15. S. Yano, H. Kazuno, N. Suzuki, T. Emura, K. Wierzba, J. Yamashita, Y. Tada, Y. Yamada, M. Fukushima and T. Asao, Bioorg. Med. Chem., 12, 3443 (2004).

16. F. Corelli, M. Botta, A. Lossani, S. Pasquini, S. Spadari and F. Focher, Il Farmaco, 59, 987 (2004).

17. A. Fassihi, C. Velazquez and E. E. Knaus, J. Heterocyclic Chem., 41, 263 (2004).

18. A. Chacko, W. Qu and H. Kung, J. Org. Chem., 73, 13, 4874 (2008).

19. S. Kumar, V. Kumar, S. Singh and S. S. Chimni, Tetrahedron Lett., 42, 30, 5073 (2001).

20. F. Zhang, A. Kulesza, S. Rani, B. Bernet and A. Vasella, Helv. Chim. Acta, 91, 1201 (2008).

21. H. A. Duong and J. Louie, Tetrahedron, 62, 7552 (2006).

22. M. Botta, R. Saladino, G. Delle Monache, G. Gentile and R. Nicoletti, Heterocycles, 43, 1687 (1996).

23. M. Aso, T. Kaneko, M. Nakamura, N. Koga and H. Suemune, Chem. Commun., 1094 (2003). 
24. J. D. White and J. Hansen, J. Org. Chem., 70, 1963 (2005).

25. N. Boudet, and P. Knochel, Org. Lett., 8, 17, 3737 (2006).

26. F. Kopp and P. Knochel, Org. Lett., 9, 9, 1639 (2007).

27. M. Médiebielle, J. Pinson and J. M. Savéant, Tetrahedron Lett., 33, 7351 (1992).

28. M. A. Ismail, H. H. Zoorob and L. Strekowski, Arkivoc, part x, 1 (2002).

29. D. Cech, R. Wohfeil, G. Etzold, Nucleic Acid Res., 2, 2183 (1975)

30. S. Fustero, J. Piera, J. F. Sanz-Cervera, S. Catalán and C. Ramírez de Arellano, Org. Lett., 6, 1417 (2004).

31. S. Fustero, S. Catalán, S. Flores, D. Jiménez, C. del Pozo, J. L. Aceña, J. F. Sanz-Cervera, and S. Mérida, QSAR Comb. Sci., 25, 753 (2006).

32. Y. Jiang, S. Chung, D. J., Krosky and J. T. Stivers, Bioorg. Med. Chem., 14, 5666 (2006).

33. R. Polo, J. M. Moretó, U. Schick and S. Ricart, Organometallic, 17, 2135 (1998).

34. A. Spinella, T. Caruso, U. Pastore and S. Ricart, J. Organomet. Chem., 684, 266 (2003).

35. G. D. Sala, A. Artillo, S. Ricart and A. Spinella, J. Organomet. Chem., 692, 1623 (2007).

36. Barluenga's protocol based on fluoride ion. J. Barluenga, F. Andina, M. A. FernándezRodriguez, P. Garcia-Garcia, I. Merino and E. Aguilar, J. Org. Chem., 69, 7352 (2004).

37. Z. Guo, Y. Zhu, T. D. Gross, F. C. Tucci, Y. Gao, M. Moorjani, P. J. Connors, Jr., M. W. Rowbottom, Y. Chen, R. S. Struthers, Q. Xie, J. Saunders, G. Reinhart, T. K. Chen, A. L. K. Bonneville and C. Chen, J. Med. Chem., 47, 1259 (2004).

38. F. C. Tucci, Y. Zhu, Z. Guo, T. D. Gross, P. J. Connors, Jr., R. S. Struthers, G. J. Reinhart, J. Saundersa and C. Chen, Bioorg. Med. Chem. Lett., 13, 3317 (2003).

39. Z. Guo, Y. Chen, C. Q. Huang, T. D. Gross, J. Pontillo, M. W. Rowbottom, J. Saunders, S. Struthers, F. C. Tucci, Q. Xie, W. Wade, Y. Zhu, D. Wua and C. Chen, Bioorg. Med. Chem. Lett., 15, 2519 (2005).

562 41. K. Pomeisl, A. Holý and R. Pohl, Tetrahedron Lett., 48, 3065 (2007).

563 42. B. Y. Oquare and J. S. Taylor, Bioconjugate Chem., 19, 2196 (2008).

564 43. T. Gazivoda, S. Raić-Malić, M. Marjanović, M. Kralj, K. Pavelić, J. Balzarini, E. De Clercq and M. Mintas, Bioorg. Med. Chem., 15, 749 (2007).

44. For reviews, see: R. A. Rossi, A. B. Pierini, A. B. Peñéñory, Chem. Rev. 103, (2003), and R. A. Rossi, Photoinduced Aromatic Nucleophilic Substitution; Chapter 16, "Synthetic Organic Photochemistry”, p 495, Marcel Dekker, New York (2005).

45. H. Wójtpwicz-Rachel, M. Migas and H. Koroniak, J. Org. Chem., 71, 8842 (2006).

46. M. Médebielle, M. A. Oturan, J. Pison and J. M. Savéant, Tetrahedron Lett., 34, 3409 (1993).

47. M. Médebielle, M. A. Oturan, J. Pison and J. M. Savéant, J. Org. Chem., 61, 1331 (1996).

48. S. S. H. Davarani, N. S. Fumani, H. Arvin-Nezhad and F. Moradi, Tetrahedron Lett., 49, 710 (2008).

575 50. F. W. Hobbs Jr., J. Org. Chem., 54, 3420 (1989). 
51. R. H. E. Hudson, G. Li and J. Tse, Tetrahedron Lett., 43, 1381 (2002).

52. F. Wojciechowski and R. H. E. Hudson, Nucleos. Nucleot. Nucl., 26, 1199 (2007).

53. T. Gazivoda, S. Raić-Malić, V. Krištafor, D. Makuc, J. Plavec, S. Bratulić, S. Kraljević-Pavelić, K. Pavelić, L. Naesens, G. Andrei, R. Snoeck, J. Balzarini and M. Mintas, Bioorg. Med. Chem., 16, 5624 (2008).

54. I. Devi and P. J. Bhuyan, Tetrahedron Lett., 46, 5727 (2005).

55. C. Zhi, Z. Long, J. Gambino, W. Xu, N. C. Brown, M. Barnes, M. Butler, W. LaMarr and G. E. Wright, J. Med. Chem., 46, 2731 (2003).

56. N. C. Brown, J. Gambino and G. E. Wright, J. Med. Chem., 20, 1186 (1977).

57. C. Zhi, Z. Long, A. Manikowski, N. C. Brown, P. M. Tarantino, K. Holm, E. J. Dix, G. E. Wright, K. A. Foster, M. M. Butler, W. A. LaMarr, D. J. Skow, I. Motorina, S. Lamothe and R. Storer, J. Med. Chem., 48, 7063 (2005).

58. G. Gasser, M. J. Belousoff, A. M. Bond and L. Spiccia, J. Org. Chem., 71, 7565 (2006).

59. A. Schnudt and M. K. Kindermann, J. Org. Chem., 62, 3910 (1997).

60. J. Asakura and M. Robins, J. Org. Chem., 55, 4928 (1990).

61. M. Elshehry, J. Balzarini and C. Meier, Synthesis, 5, 841 (2009).

62. S. Boncel, A. Gondela and K. Walczak, Curr. Org. Synth., 5, 365 (2008) and reference therein.

63. L. Paolini, E. Petricci, F. Corelli and M. Botta, Synthesis, 2, 1039 (2003).

64. R. Saladino, L. Stasi, C. Crestini, R. Nicoletti and M. Botta, Tetrahedron, 53, 7045 (1997).

65. R. Saladino, L. Stasi, R. Nicoletti, C. Crestini and M. Botta, Eur. J. Org. Chem., 2751 (1999).

66. I. Devi, H. N. Borah and P. J. Bhuyan, Tetrahedron Lett., 45, 2405 (2004).

67. B. Baruah and P. J. Bhuyan, Tetrahedron Lett., 45, 243 (2009).

68. I. Devi and P. J. Bhuyan, Tetrahedron Lett., 45, 7727 (2004).

69. M. J. Khoshkholgh, S. Balalaie, H. R. Bijanzadeh, F. Rominger and J. H Gross, Tetrahedron Lett., 49, 6965 (2008).

70. K. C. Majumdar, B. Sinha, B. Chattapadhyay and K. Ray, Tetrahedron Lett., 49, 4405 (2008).

71. S. Fustero, S. Catalán, J. Piera, J. F. Sanz-Cervera, B. Fernández and J. L. Aceña, J. Org. Chem., 71, 3910 (2006).

72. M. C. Willis, R. H. Snell, A. J. Fletcher and R. L. Woodward, Org. Lett., 8, 22, 5089 (2006).

73. S. M. Chicetti, S. P. Ahearn and A. Rivkin, Tetrahedron Lett., 49, 6081 (2008).

74. O. I. El-Sabbagh, M. E. El-Sadek, S. El-Kalyoubi and I. Iamail, Arch. Pharm. Chem. Life Sci., 340, 1 (2007).

75. R. Ghahremanzadeh, S. C. Azimi, N. Gholami and A. Bazgir, Chem. Pharm. Bull., 56, 1617 (2008).

76. H. Lee, S.-I. Lee, and S.-I.Yang, Bioorg. Med. Chem. Lett., 8, 2991 (1998).

77. G. Tudor, P. Gutierrez, A. Aguilera-Gutierrez, and E. A. Sausville, Biochem. Pharmacol., 65, 1061 (2005). 
614 78. J. A. Valderrama, M. F. González, P. Colonelli, and D. Vásquez, Synlett, 2006, 2777.

615 79. J. A. Valderrama and D. Vásquez, Tetrahedron Lett., 49, 703 (2008).

616 80. Z. Janeba, J. Balzarini, G. Andrei, R. Snoeck, E. Clercq and M. J. Robins, J. Med. Chem., 48, 617 4690 (2005).

618 81. Z. Janeba, J. Balzarini, G. Andrei, R. Snoeck, E. Clercq and M. J. Robins, Can. J. Chem., 84, 619580 (2006). 